\title{
SARS-CoV-2 DNA Vaccine INO-4800 Induces Durable Immune Responses Capable of Being Boosted in a Phase 1 Open-Label Trial
}

Kimberly A. Kraynyak, $\mathrm{PhD}^{1^{*}}$, Elliott Blackwood, $\mathrm{MS}^{1^{*}}$, Joseph Agnes, $\mathrm{PhD}^{1^{*}}$, Pablo Tebas, $\mathrm{MD}^{3}$, Mary Giffear, BS ${ }^{1}$, Dinah Amante, BS ${ }^{1}$, Emma L. Reuschel, $\mathrm{PhD}^{2}$, Mansi Purwar, $\mathrm{PhD}^{2}$, Aaron Christensen-Quick, $\mathrm{PhD}^{1}$, Neiman Liu, $\mathrm{MS}^{1}$, Viviane M. Andrade, $\mathrm{PhD}^{1}$, Malissa C. Diehl, $\mathrm{PhD}^{1}$, Snehal Wani, $\mathrm{MS}^{1}$, Martyna Lupicka, $\mathrm{PhD}^{1}$, Albert Sylvester, BS ${ }^{1}$, Matthew P. Morrow, $\mathrm{PhD}^{1}$, Patrick Pezzoli, BS ${ }^{1}$, Trevor McMullan, MS¹, Abhijeet J. Kulkarni, MS², Faraz I. Zaidi, MS², Drew Frase, $\mathrm{MS}^{2}$, Kevin Liaw, $\mathrm{PhD}^{2}$, Trevor R.F. Smith, $\mathrm{PhD}^{1}$, Stephanie J. Ramos, $\mathrm{PhD}^{1}$, John Ervin, $\mathrm{MD}^{4}$, Mark Adams $\mathrm{MD}^{5}$, Jessica Lee, $\mathrm{MPH}^{1}$, Michael Dallas, $\mathrm{PhD}^{1}$, Ami Shah Brown, $\mathrm{PhD}$, $\mathrm{MPH}^{1}$, Jacqueline E. Shea, $\mathrm{PhD}^{1}$, J. Joseph Kim, $\mathrm{PhD}^{1}$, David B. Weiner, $\mathrm{PhD}^{2}$, Kate E. Broderick, $\mathrm{PhD}^{1}$, Laurent M. Humeau, $\mathrm{PhD}^{1 \#}$, Jean D. Boyer, $\mathrm{PhD}^{1}$, Mammen P. Mammen Jr., $\mathrm{MD}^{1}$

*Authors contributing equally

\section{Affiliations:}

${ }^{1}$ Inovio Pharmaceuticals, Plymouth Meeting, PA, 19462, USA

${ }^{2}$ Vaccine and Immunotherapy Center, Wistar Institute, Philadelphia, PA, 19104, USA

${ }^{3}$ Hospital of the University of Pennsylvania, Philadelphia, PA, USA

${ }^{4}$ Alliance for Multispecialty Research, Kansas City, MO, USA

${ }^{5}$ Alliance for Multispecialty Research, Lexington, KY, USA

1- NOTE: This preprint reports new research that has not been certified by peer review and should not be used to guide clinical practice. 


\section{Summary:}

Two-milligram dose of INO-4800, a DNA-based vaccine encoding the SARS-CoV-2 spike protein, appears safe and well-tolerated and elicits humoral and cell-mediated immunity persisting to 6 months after a second dose. A third dose 6-10.5 months later significantly boosts immune responses.

Running Title: SARS-CoV-2 DNA Vaccine Can be Boosted

Abstract Word Count: 200

Text Word Count: 3494

Meeting presentations:

In part at ID Week (September 2021), Virtual (Abstract \#: 571)

\#Corresponding author:

Laurent M. Humeau, PhD

Inovio Pharmaceuticals

660 W. Germantown Pike, Suite \#110

Plymouth Meeting, PA, 19462, USA.

Phone: (858) 410-3140

laurent.humeau@inovio.com 
medRxiv preprint doi: https://doi.org/10.1101/2021.10.06.21264584; this version posted January 25, 2022. The copyright holder for this preprint

(which was not certified by peer review) is the author/funder, who has granted medRxiv a license to display the preprint in perpetuity.

All rights reserved. No reuse allowed without permission.

Alternate corresponding author:

Kimberly A. Kraynyak, PhD

Inovio Pharmaceuticals

660 W. Germantown Pike, Suite \#110

Plymouth Meeting, PA, 19462, USA

Phone: (267) 440-4216

kim.kraynyak@inovio.com

3- 
medRxiv preprint doi: https://doi.org/10.1101/2021.10.06.21264584; this version posted January 25, 2022. The copyright holder for this preprint (which was not certified by peer review) is the author/funder, who has granted medRxiv a license to display the preprint in perpetuity.

All rights reserved. No reuse allowed without permission.

\section{Abstract}

Background: Additional SARS-CoV-2 vaccines that are safe and effective as primary vaccines and boosters remain urgently needed to combat the COVID-19 pandemic. We describe the safety and durability of the immune responses following two primary doses and a homologous booster dose of an investigational DNA vaccine (INO-4800) targeting the full-length spike antigen.

Methods: Three dosage strengths of INO-4800 $(0.5 \mathrm{mg}, 1.0 \mathrm{mg}$, and $2.0 \mathrm{mg})$ were evaluated in 120 age-stratified healthy adults. Intradermal injection of INO-4800 followed by electroporation at 0 and 4 weeks preceded an optional booster 6-10.5 months after the second dose.

Results: INO-4800 appeared well tolerated, with no treatment-related serious adverse events. Most adverse events were mild and did not increase in frequency with age and subsequent dosing. A durable antibody response was observed 6 months following the second dose; a homologous booster dose significantly increased immune responses. Cytokine producing T cells and activated CD8+ T cells with lytic potential were significantly increased in the $2.0 \mathrm{mg}$ dose group.

Conclusion: INO-4800 was well tolerated in a 2-dose primary series and as a homologous booster in all adults, including the elderly. These results support further development of INO-4800 for use as a primary vaccine and as a booster.

Keywords: SARS-CoV-2; Clinical trial; DNA Vaccine; INO-4800; COVID-19; Safety; Immunogenicity; Booster

Trial Registration: ClinicalTrials.gov NCT04336410 
medRxiv preprint doi: https://doi.org/10.1101/2021.10.06.21264584; this version posted January 25, 2022. The copyright holder for this preprint (which was not certified by peer review) is the author/funder, who has granted medRxiv a license to display the preprint in perpetuity.

All rights reserved. No reuse allowed without permission.

\section{Introduction}

Despite aggressive vaccination campaigns, most of the world's population remains unvaccinated and susceptible to COVID-19, the disease caused by SARS-CoV-2[1]. The urgent need remains for additional safe and effective vaccines that are affordable, scalable, and can be distributed to countries where the infrastructure may not be supportive of ultra-cold chain transport and storage.

Attachment of SARS-CoV-2 to host cells is mediated by binding of the viral spike (S) protein to angiotensin converting enzyme 2 (ACE2) receptors on host cells[2]. Humoral responses against the spike protein prevent the virus from accessing host cells[3], and this strategy has led to the development of several vaccines targeting SARS-CoV-2 (reviewed by $[4,5]$ ).

INO-4800 is an investigational optimized DNA vaccine, encoding the SARS-CoV-2 S protein[6], injected intradermally followed by in vivo electroporation[7]. This approach potentially offers several advantages, including induction of humoral and cellular immunity, favorable tolerability and thermal stability profiles, and ease of manufacture[8, 9]. Plasmid DNA-based products in development by this sponsor have been shown to be stable at $2-8^{\circ} \mathrm{C}$ for $3-5$ years, at room temperature $\left(25^{\circ} \mathrm{C}\right)$ for least 1 year, and at $37^{\circ} \mathrm{C}$ for 1 month (unpublished data), and is in line with earlier reports on the stability of pharmaceutical grade plasmid DNA[10].

Preclinical studies have shown INO-4800 to be immunogenic[6], with durable cellular and neutralizing antibody responses[11]. INO-4800 provided protection against viral challenge in nonhuman primates with no evidence of vaccine-enhanced disease[12], and elicited neutralizing antibodies reactive against multiple variants of concern (VOCs)[13].

The preliminary safety and immunogenicity of INO-4800 in both Phase 1 and Phase 2 clinical studies have been previously reported[14, 15]. The earlier analysis[14] demonstrated that two doses of INO-4800 administered one month apart were well tolerated in 38 healthy participants 18-50 years of age and induced neutralizing antibodies and/or T-cells. Here we describe the 
medRxiv preprint doi: https://doi.org/10.1101/2021.10.06.21264584; this version posted January 25, 2022. The copyright holder for this preprint (which was not certified by peer review) is the author/funder, who has granted medRxiv a license to display the preprint in perpetuity.

All rights reserved. No reuse allowed without permission.

25 durability of that response at 6 months following the second dose, as well as the safety and

26 immunogenicity of the 2-dose regimen in older and elderly participants, including following a

27 subsequent homologous booster dose.

28

29 Methods

$30 \quad$ Trial Design and Participants

31 This Phase 1, open-label, multi-center trial (NCT04336410) evaluated the safety, tolerability, and

32 immunogenicity of INO-4800 injected intradermally (ID) followed by electroporation (EP). A total

33 of 120 healthy participants without a known history of COVID-19 were assigned to receive a

$340.5 \mathrm{mg}, 1.0 \mathrm{mg}$, or $2.0 \mathrm{mg}$ dose of INO-4800 in a 2-dose regimen (weeks 0 and 4 ) and a subsequent

35 optional booster dose no earlier than 8 weeks after dose 2. An equal number of participants were

36 enrolled in each dose group $(n=40)$ and further stratified by age groups [18-50 years of age; $n=20$,

$3751-64$ years of age; $n=10$, and $\geq 65$ years of age; $n=10]$.

38 The trial was approved by the institutional review board of each clinical site, all participants

39 provided written informed consent prior to enrollment. The trial was conducted under current Good

40 Clinical Practices (GCP).

41

42 DNA Vaccine INO-4800

43 INO-4800 was previously described $[6,14]$ and encodes the full-length sequence of the SARS-

44 CoV-2 spike glycoprotein derived from the Wuhan strain based on an optimized synthetic 
medRxiv preprint doi: https://doi.org/10.1101/2021.10.06.21264584; this version posted January 25, 2022. The copyright holder for this preprint (which was not certified by peer review) is the author/funder, who has granted medRxiv a license to display the preprint in perpetuity.

All rights reserved. No reuse allowed without permission. sequence created using a proprietary algorithm. The final vaccine drug product, manufactured under Good Manufacturing Practices, was formulated at $10 \mathrm{mg} / \mathrm{mL}$ in saline sodium citrate buffer.

INO-4800 is injected ID followed by EP using the CELLECTRA® 2000 device that generates a controlled electric field at the injection site to enhance the cellular uptake and expression of the DNA plasmid as previously described[16, 17]. The device delivers a total of four electrical pulses per EP, each of $52 \mathrm{msec}$ in duration, at current of 0.2 Amp and voltage of 40-200 per pulse.

\section{Endpoints}

Primary safety endpoints included incidence of adverse events (AEs) using the "Toxicity Grading Scale for Healthy Adult and Adolescent Volunteers Enrolled in Preventive Vaccine Clinical Trial" including frequency and severity of injection site reactions. Primary immunological endpoints included the measurement of SARS-CoV-2 Spike glycoprotein antigen-specific binding antibodies as well as the measurement of antigen-specific cellular immune responses by IFN- $\gamma$, ELISPOT and flow cytometry assays. Endpoints reflected in this publication are inclusive of 6 months after second dose (non-boosted participants) and, when applicable, 2 weeks after booster dose.

\section{$\underline{\text { Trial Procedures }}$}

Vaccine was administered in $0.1 \mathrm{ml}$ ID injections in the deltoid followed by EP at the injection site. At each dosing visit, either a single injection for $0.5 \mathrm{mg}$ and $1.0 \mathrm{mg}$ dose groups or two injections for 2.0mg dose group were given, one in each deltoid.

Forty participants $18-50$ years were enrolled sequentially into $1.0 \mathrm{mg}$ and $2.0 \mathrm{mg}$ dose groups with a safety run-in period[14]. The trial design was expanded to include older participants in all dosing groups (including a $0.5 \mathrm{mg}$ dose level). Upon favorable safety assessment review by an 
medRxiv preprint doi: https://doi.org/10.1101/2021.10.06.21264584; this version posted January 25, 2022. The copyright holder for this preprint (which was not certified by peer review) is the author/funder, who has granted medRxiv a license to display the preprint in perpetuity.

All rights reserved. No reuse allowed without permission.

independent Data Safety Monitoring Board (DSMB) of Week 1 data for $0.5 \mathrm{mg}$ dose group participants aged $51-64$ years and $\geq 65$ years, enrollment of the corresponding age strata in the $1.0 \mathrm{mg}$ and subsequently $2.0 \mathrm{mg}$ dose groups was initiated.

71 Participants were assessed for safety (complete blood count, serum chemistry, and urinalysis),

72 including local and systemic AEs, at screening, Week 0 (Dose 1), next day phone call, and Weeks

73 1, 4 (Dose 2), 6, 8, 12, 28, 40 and 52. Blood immunology collections occurred at all clinic visits

74 except Week 1. After the Week 12 visit, participants who consented to the optional booster dose

75 were transitioned to an extended schedule of events to include the booster dose (Dose 3) and

76 subsequent visits for safety at $2,12,24,36$, and 48 weeks following the booster dose with blood

77 immunology collections at all clinic visits except 36 weeks.

The DSMB reviewed laboratory and AE data for the participants up to 24 weeks after the second dose (non-boosted) and 2 weeks after booster dose.

\section{$81 \quad$ Protocol Eligibility}

82 Key inclusion criteria included: healthy adults aged at least 18 years; and Body Mass Index of 18$8330 \mathrm{~kg} / \mathrm{m}^{2}$ at screening. Key exclusion criteria included: individuals in a current occupation with high 84 risk of exposure to SARS-CoV-2; previous known exposure to SARS-CoV-2 or receipt of an 85 investigational product for the prevention or treatment of COVID-19; autoimmune or 86 immunosuppression as a result of underlying illness or treatment; hypersensitivity or severe 87 allergic reactions to vaccines or drugs; and medical conditions that increased risk for severe 88 COVID-19. 
medRxiv preprint doi: https://doi.org/10.1101/2021.10.06.21264584; this version posted January 25, 2022. The copyright holder for this preprint (which was not certified by peer review) is the author/funder, who has granted medRxiv a license to display the preprint in perpetuity.

All rights reserved. No reuse allowed without permission.

$\underline{\text { Immunogenicity Assessment Methods }}$

Samples were collected at timepoints described above with screening and pre-dose 1 samples considered baseline. Peripheral blood mononuclear cells (PBMCs) were collected as previously described[14]. After isolation, PBMCs were stored in the vapor phase of a liquid nitrogen freezer until analysis, while serum samples were stored at $-80^{\circ} \mathrm{C}$. Eight participants were excluded from the immunogenicity analyses due to a positive ELISA titer to the SARS-CoV-2 nucleoprotein, suggesting SARS-CoV-2 infection

SARS-CoV-2 Pseudovirus Neutralization Assay: Serum samples were measured using a pseudovirus neutralization assay as described previously[15]. Data was reported as $I_{50}$, which is the reciprocal serum dilution resulting in $50 \%$ inhibition of infectivity by comparison to control wells with no serum samples added. Supplementary methods show additional information.

\section{SARS-CoV-2 Spike Enzyme-Linked Immunosorbent Assay (ELISA): Binding antibodies to SARS-} CoV-2 spike protein were measured by ELISA as described previously[15]. SARS-CoV-2 spike antibody concentrations were determined by interpolation from a dilution curve of SARS-CoV-2 convalescent plasma with an assigned concentration of 20,000 Units/mL. Supplementary methods show additional information.

SARS-CoV-2 Spike ELISpot Assay Description: The SARS-CoV-2 spike antigen-specific IFN-Y T-cell response was measured as described previously[14]. Values were reported as the mean spot-forming units per million PBMCs across three triplicate wells after background subtraction using DMSO-only negative control wells. Supplementary methods show additional information.

INO-4800 SARS-CoV-2 Spike Flow Cytometry Assays: PBMCs were also assessed in Intracellular Cytokine Staining (ICS) and Lytic Granule Loading (LGL) assays. The ICS assay was performed as previously described[14]. The LGL assay was also performed as reported 
medRxiv preprint doi: https://doi.org/10.1101/2021.10.06.21264584; this version posted January 25, 2022. The copyright holder for this preprint (which was not certified by peer review) is the author/funder, who has granted medRxiv a license to display the preprint in perpetuity.

All rights reserved. No reuse allowed without permission.

113 previously[18] following stimulation with overlapping peptides to the full-length spike protein to

114 measure CD8+T cell activation and capacity to produce lytic proteins.

115 Statistical Analysis

116 No formal power analysis was applicable to this trial. Descriptive statistics were used to

117 summarize the safety endpoints based on the safety population: proportions of participants with

118 AEs, through 6 months following dose 2 (non-boosted participants) or 2 weeks following booster

119 dose. The safety population included all participants who received at least one dose of INO-4800

120 and were grouped by age and the dose of INO-4800. Post-hoc within subject analyses of post-

121 vaccination minus pre-vaccination paired differences in SARS-CoV-2 neutralization and ELISA

122 spike responses (on the natural log-scale, with a paired t-test), ELISpot responses (with Wilcoxon

123 signed-rank tests), and flow assay responses (with Wilcoxon signed-rank tests) were performed. 
medRxiv preprint doi: https://doi.org/10.1101/2021.10.06.21264584; this version posted January 25, 2022. The copyright holder for this preprint (which was not certified by peer review) is the author/funder, who has granted medRxiv a license to display the preprint in perpetuity.

124 Results

125 Trial Population Demographics

126 Between 06 April 2020 and 07 July 2020, 154 participants were screened and 120 enrolled into

127 the trial (Figure 1). The median age was 50.5 years (range 18 to 86 years). Participants were $57.5 \%$ female $(69 / 120)$ and $42.5 \%$ male $(51 / 120)$ (Table 1$).$ Most participants were white $(94.2 \%$, 129 113/120).

$131 \quad$ Vaccine Safety and Tolerability

132 A total of 117 of $120(97.5 \%)$ participants received both doses. One participant in the $2.0 \mathrm{mg}$ 133 group discontinued trial participation prior to receiving the second dose solely due to lack of 134 transportation to the clinical site. Two participants in the $0.5 \mathrm{mg}$ group did not receive the second 135 dose due to exclusionary eligibility criteria (hypertension) having been determined following Dose 1; (Figure 1).

137 Ninety-nine of 120 (82.5\%) participants consented to and received the booster dose, 138 approximately 6 to 10.5 months following the second dose. Reasons for not receiving booster 139 dose included receipt of another SARS-CoV-2 vaccine (available under Emergency Use 140 Authorization), new medical condition precluding participation (having had COVID-19, pregnancy 141 or hypertension), or loss to follow-up.

142 A total of 34 treatment-related local and systemic AEs were reported by 18 participants. Thirty143 one AEs were Grade 1 (mild) in severity and comprised mostly injection site reactions. Three 144 treatment-related Grade 2 (moderate) AEs were reported as lethargy, abdominal pain, and 145 injection site pruritus. There were no febrile reactions reported. No participants discontinued due 146 to AEs. No treatment-related SAEs were reported. There were no abnormal laboratory values that 
medRxiv preprint doi: https://doi.org/10.1101/2021.10.06.21264584; this version posted January 25, 2022. The copyright holder for this preprint (which was not certified by peer review) is the author/funder, who has granted medRxiv a license to display the preprint in perpetuity.

All rights reserved. No reuse allowed without permission.

were deemed treatment-related and clinically significant by the Investigators. There was no increase in the number of participants who experienced related AEs in the $2.0 \mathrm{mg}$ group (12.5\%, $5 / 40)$, compared to that in the $1.0 \mathrm{mg}$ group $(15 \%, 6 / 40)$ or the $0.5 \mathrm{mg}$ group $(17.5 \%, 7 / 40)$. In addition, there was no appreciable increase in the frequency of AEs with the second or booster doses when compared to the first dose (Figure 2). A decrease in frequency of treatment-related AEs in the older and elderly age cohorts was observed when compared to the younger age group (Supplementary Table 4).

INO-4800 induces durable humoral immune responses capable of being boosted: Induction of antibodies against SARS-CoV-2 following vaccination with INO-4800 was measured from sera. The functionality of antibodies was assessed using a pseudovirus neutralization assay. All dose groups induced neutralizing antibodies that peaked two weeks post second dose (GMTs- 14.9, 19.1, 54.1 in the $0.5 \mathrm{mg}, 1.0 \mathrm{mg}$ and $2.0 \mathrm{mg}$ dose groups, respectively) (Figure 3A, left panel, Supplementary Table 1). These increased responses were statistically significant over baseline in the $2.0 \mathrm{mg}$ dose group for each time point through study week 28 , approximately 6 months after dose 2 (Figure 3A, table). Following administration of a booster dose, statistically significant increases over pre-boost titers were observed in all dose groups (GMTs- 58.7, 76.1, 100 in the $0.5 \mathrm{mg}, 1.0 \mathrm{mg}$ and $2.0 \mathrm{mg}$ dose groups, respectively; all $\mathrm{P}<0.001$ ) (Figure 3A, right panel, Supplementary Table 1). The $2.0 \mathrm{mg}$ dose group had a $12.8(95 \% \mathrm{Cl} 6.3,26.0)$ geometric fold rise (GMFR) over pre-boost titers, the highest of any dose group. Neutralization titers by participant age are shown in Supplementary Figure 1A; GMTs were numerically lower in the older age groups but statistically significantly higher than baseline at week 6 in the $2.0 \mathrm{mg}$ dose 
medRxiv preprint doi: https://doi.org/10.1101/2021.10.06.21264584; this version posted January 25, 2022. The copyright holder for this preprint (which was not certified by peer review) is the author/funder, who has granted medRxiv a license to display the preprint in perpetuity.

All rights reserved. No reuse allowed without permission.

group. Plasma samples from convalescent samples had a GMT of 922 and ranged from 10 to 13,249 (Supplementary Figure 2A).

Antibodies to the spike trimer protein were measured in a binding ELISA. All three groups exhibited binding antibodies that peaked four weeks following dose 2 (Geometric Mean Titers, GMTs- 428.5, 595.9, 678.0 in the $0.5 \mathrm{mg}, 1.0 \mathrm{mg}$ and $2.0 \mathrm{mg}$ dose groups, respectively) (Figure 3B, left panel, Supplementary Table 2). Increases over baseline were observed in all participants who received the $2.0 \mathrm{mg}$ dose, but not in all participants in the other groups, and GMTs were statistically significantly higher than baseline 6 months following dose 2 (GMTs$250.1,215.3,407.2$ in the $0.5 \mathrm{mg}, 1.0 \mathrm{mg}$ and $2.0 \mathrm{mg}$ dose groups, respectively; all $\mathrm{P} \leq 0.026$ ). Following administration of a booster dose, statistically significant increases over pre-boost titers were observed in all dose groups (GMTs- 1963.8, 3685, 5953 in the $0.5 \mathrm{mg}, 1.0 \mathrm{mg}$ and $2.0 \mathrm{mg}$ dose groups, respectively; all $\mathrm{P} \leq 0.007$ ) (Figure 3B, right panel, Supplementary Table 2). The $2.0 \mathrm{mg}$ dose group had a $20.8(95 \% \mathrm{Cl} 13.9,31.2)$ GMFR over pre-boost titers which was the highest of any dose group. ELISA binding titers by participant age are shown in Supplementary Figure 1B. Plasma samples from convalescent samples had a GMT of 19,444 and ranged from 330 to 247,200 (Supplementary Figure 2B).

INO-4800 induces cellular immune responses capable of being boosted

Interferon-gamma (IFN $\gamma$ ) ELISpot was performed on PBMCs. Increases in spot forming units (SFU) per million PBMCs over baseline are shown in Figure 4A, left panel. Magnitudes of IFN $\gamma$ peaked at week 6 for the $0.5 \mathrm{mg}$ and $2.0 \mathrm{mg}$ dose groups (median 19.4 and 43.3, respectively) and at week 8 for the $1.0 \mathrm{mg}$ dose group (median 17.8). Six months following dose 2 , magnitudes remained high in the $2.0 \mathrm{mg}$ dose group (median 19.6). Of note, magnitudes in the $1.0 \mathrm{mg}$ and $2.0 \mathrm{mg}$ dose groups were statistically significantly increased following the booster dose $(\mathrm{P}=0.018$ and $\mathrm{P}=0.008$, respectively) (Figure 4A, right panel). The $2.0 \mathrm{mg}$ dose group had a difference in 
medRxiv preprint doi: https://doi.org/10.1101/2021.10.06.21264584; this version posted January 25, 2022. The copyright holder for this preprint (which was not certified by peer review) is the author/funder, who has granted medRxiv a license to display the preprint in perpetuity.

All rights reserved. No reuse allowed without permission.

medians of 10 following the booster, resulting in the highest post-boost increase of any dose group. ELISpot responses by participant age are shown in Supplementary Figure 3A.

\section{INO-4800 induces cytokine producing $T$ cells and activated CD8+T cells with lytic potential}

The contribution of SARS-CoV-2 specific $\mathrm{CD}^{+}$and $\mathrm{CD}^{+}{ }^{+}$cells was assessed by intracellular cytokine staining (ICS) on participants following 2 doses, Figure 4B-C. The median frequency of CD4+T cells producing IFN $\gamma$ increased following vaccination in all three dose groups of INO-4800, and the frequency of CD4+T cells producing TNF $\alpha$ was statistically significantly increased in the $2.0 \mathrm{mg}$ dose group $(\mathrm{P}<0.001)$ (Figure 4B). The frequency of $\mathrm{CD} 8+\mathrm{T}$ cells producing TNF $\alpha$ was statistically significantly increased following vaccination in all three dose groups of INO-4800 (All $\mathrm{P} \leq 0.041$ ) (Figure 4C). The $2.0 \mathrm{mg}$ dose group had the highest difference in medians for CD8+T cells producing any response, IFN $\gamma$ and TNF $\alpha(0.066,0.026$, and 0.011 respectively). Responses by participant age are shown in Supplementary Figure 3B-C.

SARS-CoV-2 specific CD8+T cells were also characterized on a subset of participants with remaining sample following 3 doses by a flow cytometry assay that included activation markers CD69 and CD137. The median frequency of CD8+CD69+CD137+ cells increased following immunization with $2.0 \mathrm{mg}$ of INO-4800, with a difference in the medians of 0.072 (Figure 5A, left panel). Further characterization of these activated cells, including the co-expression of proteins utilized in cytolytic killing (granzyme A, granzyme B, perforin or granulysin) revealed a statistically significant increase in both the $1.0 \mathrm{mg}(\mathrm{P}=0.008)$ and $2.0 \mathrm{mg}(\mathrm{P}=0.003)$ dose groups (Figure 5A middle and right panels). The $2.0 \mathrm{mg}$ dose group had a difference in medians of 0.085 in the CD69+CD137+ population co-expressing perforin and granzymes A and B and 0.054 in the population co-expressing granulysin. CD8+T cells expressing the activation marker CD38 and proliferation marker Ki67 were also assessed (Figure 5B and C, respectively). The frequency of SARS-CoV-2 specific CD38+CD8+T cells statistically significantly increased following $2.0 \mathrm{mg}$ 
medRxiv preprint doi: https://doi.org/10.1101/2021.10.06.21264584; this version posted January 25, 2022. The copyright holder for this preprint (which was not certified by peer review) is the author/funder, who has granted medRxiv a license to display the preprint in perpetuity.

All rights reserved. No reuse allowed without permission.

217 of INO-4800 ( $\mathrm{P}=0.016)$, with a difference in medians of 1.45 (Figure 5B, left panel).

218 CD38+CD8+T cells with lytic potential (Figure 5B middle and right panels) statistically 219 significantly increased following $2.0 \mathrm{mg}$ of INO-4800 $(\mathrm{P}<0.001)$. Following immunization with 2.0

$220 \mathrm{mg}$ of INO-4800, the mean frequency of activated CD8+T cells expressing granzymes A and B

221 and perforin was $1.7 \%$ with a difference in medians of 0.710 and those expressing granulysin was

$2221.8 \%$ with a difference in medians of 0.433 (Figure 5B middle and right panels). Statistically

223 significant increases in the frequency of these CTL phenotypes were also observed in the $1.0 \mathrm{mg}$

224 dose group $(\mathrm{P} \leq 0.012)$ (Figure 5B middle and right panels). The $2.0 \mathrm{mg}$ dose group had the

225 highest frequencies of CD8+T cells expressing Ki67 with a difference in medians of 0.367 and

226 Ki67 with cytolytic proteins: 0.296 (GrzA+GrzB+Prf+) and 0.230 (Gnly+). All three Ki67+

227 populations were statistically significantly increased in the $2.0 \mathrm{mg}$ dose group $(\mathrm{P} \leq 0.001$; Figure

228 5C). The $2.0 \mathrm{mg}$ dose group consistently showed the highest median responses across all 229 phenotypes assessed compared to the other groups.

231 Discussion

232 This report provides results for the expansion of a Phase 1 trial to include older and elderly 233 participants and an optional booster dose with the aim to evaluate the safety, tolerability, and 234 immunogenicity of INO-4800, a SARS-CoV-2 vaccine encoding the S protein[14], including the 235 immune responses 6 months following dose 2 and 2 weeks following the optional booster dose.

236 INO-4800 appeared to be well-tolerated at all three dose levels, with no treatment-related serious 237 adverse events (SAEs) reported. Most AEs were mild in severity and did not increase in frequency 238 with age and subsequent dosing. These results are consistent with the severity of AEs and lack 239 of treatment-related SAEs observed in the U.S. Phase 2 trial comparing the $1.0 \mathrm{mg}$ and $2.0 \mathrm{mg}$ 240 doses of INO-4800 in approximately 400 subjects[15] and those studies conducted outside the 
medRxiv preprint doi: https://doi.org/10.1101/2021.10.06.21264584; this version posted January 25, 2022. The copyright holder for this preprint (which was not certified by peer review) is the author/funder, who has granted medRxiv a license to display the preprint in perpetuity.

All rights reserved. No reuse allowed without permission.

241 U.S. by Inovio collaborators (International Vaccine Institute, Advaccine - manuscripts in

242 preparation). The lower frequency of treatment-related AEs reported by older and elderly

243 participants in our study is consistent with findings of other studies evaluating SARS-CoV-2

244 vaccines[19, 20]. Weaker inflammatory reactions consequent to immunosenescence may explain

245 the lower incidence of AEs among elderly participants[21, 22].

246 Induction of both humoral and cellular responses were observed across all three dose groups,

247 inclusive of binding and neutralizing antibodies and cytokine producing $\mathrm{T}$ cells as well as

248 exhibiting lytic potential. Immunization with the $2.0 \mathrm{mg}$ dose resulted in the highest GMTs of

249 neutralizing and binding antibodies as well as the highest magnitudes of IFN $\gamma$ production to SARS-

250 CoV-2 of any dose in all age groups tested, and the increases in antibody levels were statistically

251 significant above baseline at 6 months following dose 2. Importantly, increases in both humoral

252 and cellular immune responses were statistically significant following the booster dose.

253 The contribution of the CD8+T cell response to vaccine efficacy has become increasingly

254 recognized as they have been detected early after vaccination[23] and due to their role in

255 controlling infection[24, 25]. Specifically, it has been established that CD8+T cells expressing

256 cytokines such as IFN $\gamma$ and TNF $\alpha$ as well as markers involved in activation status and proliferation

257 such as CD38 and Ki67 contribute to limiting disease severity during SARS-CoV-2 infection[24].

258 Additional studies have identified the expression of CD69 and CD137 on SARS-CoV-2 specific

259 CD8+T cells being associated with less severe disease[25]. This expanded Phase 1 trial

260 demonstrates that immunization with INO-4800 induces SARS-CoV-2 specific CD8+T cells

261 exhibiting these specific characteristics, suggesting the induction of a vaccine-induced cellular

262 response that has potential to protect against severe COVID-19. As VoCs continue to emerge,

263 the generation of cross-reactive activated CD8+T cells with lytic potential is likely to play an

264 important role in preventing severe disease. We have previously demonstrated that vaccination

265 with INO-4800 induces T cells and neutralizing antibodies that are active against the parental 
medRxiv preprint doi: https://doi.org/10.1101/2021.10.06.21264584; this version posted January 25, 2022. The copyright holder for this preprint (which was not certified by peer review) is the author/funder, who has granted medRxiv a license to display the preprint in perpetuity.

All rights reserved. No reuse allowed without permission.

SARS-CoV-2 strain as well as the B.1.1.7, B.1.351, and P.1 VoCs[26]. We acknowledge

267 limitations to this trial that include the relatively small study population and the limited number of

268 PBMCs available for testing across more than one assay. This trial was not powered to formally

269 compare immune responses between dose groups or age stratifications. In addition, due to

270 different immune assays and methodologies employed by various groups, it is not possible to

271 directly compare immune responses observed in this trial to those elicited from other vaccine

272 platforms or to determine if the magnitudes observed in this trial are sufficient to confer clinical

273 benefit.

274 The immune responses observed in the current trial and in our larger Phase 2 trial[15] support

275 advancing the $2.0 \mathrm{mg}$ dose of INO-4800 to a Phase 3 efficacy evaluation. This dose has elicited

276 the highest binding and neutralizing antibody titers, the highest T-cell cytokine production from

277 both CD4+ and CD8+T cells, and the highest expression of markers associated with attenuation

278 of severe COVID-19 on CD8+T cells.

279 This trial demonstrated that immune responses elicited by a 2-dose primary series of INO-4800

280 could be boosted by a third dose without safety or tolerability concerns and positions INO-4800

281 as an important candidate for continued development as a stand-alone SARS-CoV-2 vaccine, as

282 well as for continued examination in combination approaches. The potential ability to administer

283 INO-4800 multiple times, with high tolerability, along with its ease of scalability and

284 thermostability, contribute to its potential value in combatting the COVID-19 pandemic. 
medRxiv preprint doi: https://doi.org/10.1101/2021.10.06.21264584; this version posted January 25, 2022. The copyright holder for this preprint (which was not certified by peer review) is the author/funder, who has granted medRxiv a license to display the preprint in perpetuity.

\section{Declaration of Interests}

KAK, EB, JA, MG, DA, ACQ, NL, VA, MD, SW, ML, AS, MPM, PP, TM, TRFS, SJR, JL, MD, ASB, JES, JJK, KEB, LMH, JDB, MPM, Jr. report grants from Coalition for Epidemic Preparedness Innovations, during the conduct of the trial; other from Inovio Pharmaceuticals, outside the submitted work. PT, ELR, MP, AJK, FIZ, DF, KL, JE, MA, and DBW report grants from Coalition for Epidemic Preparedness Innovations, during the conduct of the trial. D.B.W. participates in industry collaborations and has received renumeration for individual services. In the interest of disclosure, D.B.W. reports the following paid associations with commercial partners: Pfizer (Advisory Board), Geneos (Advisory, SRA), Advaccine (Advisory) Astrazeneca (Advisory, Speaker), Inovio (BOD, SRA, Stock ownership), Sanofi (Advisory Board), BBI (Advisory Board, SRA). All other authors declare no potential conflicts of interest.

\section{Funding}

This work is funded by the Coalition for Epidemic Preparedness Innovations (CEPI) and Inovio Pharmaceuticals, Inc.

\section{Acknowledgments}

The investigators and sponsor express their gratitude for the contribution of all the trial participants and the invaluable advice of the independent Data Safety Monitoring Board. Feedback from the peer reviewers is gratefully acknowledged. We also acknowledge the broader support from the various teams within Inovio Pharmaceuticals (Ning Jiang, MD, PhD; Greta Kcomt Del Rio, BS; Alysia Ryan, BS; Dennis Van De Goor, MS; Kelly Morales, BS; Jacob Walton, BS; Srujan Vadlamudi, BS; David Valenta, PhD; EJ Brandreth, MBA; Dan Jordan, BS; Robert J. Juba Jr, MS; Stephen Kemmerrer, BSME, MBA, PE; Timothy Herring, MPH; Susan Duff, BS; and Prasad 
medRxiv preprint doi: https://doi.org/10.1101/2021.10.06.21264584; this version posted January 25, 2022. The copyright holder for this preprint (which was not certified by peer review) is the author/funder, who has granted medRxiv a license to display the preprint in perpetuity. All rights reserved. No reuse allowed without permission.

Kulkarni, PhD, CMPP), the Wistar Institute (Dr. Ziyang Xu and Edgar Tello Ruiz), the National Infections Service, Public Health England (Naomi Coombes, PhD and Mike Elmore, PhD), Hospital of the University of Pennsylvania (Joseph Quinn, RN), and the Alliance for Multispecialty Research, Kansas City, MO and Lexington, KY. 
medRxiv preprint doi: https://doi.org/10.1101/2021.10.06.21264584; this version posted January 25, 2022. The copyright holder for this preprint (which was not certified by peer review) is the author/funder, who has granted medRxiv a license to display the preprint in perpetuity.

All rights reserved. No reuse allowed without permission.

\section{References}

1. Katz IT, Weintraub R, Bekker LG, Brandt AM. From Vaccine Nationalism to Vaccine Equity - Finding a Path Forward. N Engl J Med 2021; 384:1281-3.

2. Walls AC, Park Y-J, Tortorici MA, Wall A, McGuire AT, Veesler D. Structure, Function, and Antigenicity of the SARS-CoV-2 Spike Glycoprotein. Cell 2020; 181:281-92.e6.

3. Carrillo J, Izquierdo-Useros N, Avila-Nieto C, Pradenas E, Clotet B, Blanco J. Humoral immune responses and neutralizing antibodies against SARS-CoV-2; implications in pathogenesis and protective immunity. Biochem Biophys Res Commun 2021; 538:187-91.

4. Liu Q, Qin C, Liu M, Liu J. Effectiveness and safety of SARS-CoV-2 vaccine in real-world studies: a systematic review and meta-analysis. Infect Dis Poverty 2021; 10:132.

5. Sharif N, Alzahrani KJ, Ahmed SN, Dey SK. Efficacy, Immunogenicity and Safety of COVID-19 Vaccines: A Systematic Review and Meta-Analysis. Front Immunol 2021; 12:714170.

6. Smith TRF, Patel A, Ramos S, et al. Immunogenicity of a DNA vaccine candidate for COVID-19. Nat Commun 2020; 11:2601.

7. Gary EN, Weiner DB. DNA vaccines: prime time is now. Curr Opin Immunol 2020; 65:21-7.

8. Crommelin DJA, Anchordoquy TJ, Volkin DB, Jiskoot W, Mastrobattista E. Addressing the Cold Reality of mRNA Vaccine Stability. J Pharm Sci 2021; 110:997-1001.

9. Liu MA. A Comparison of Plasmid DNA and mRNA as Vaccine Technologies. Vaccines (Basel) 2019;

7:37.

10. Middaugh CR, Evans RK, Montgomery DL, Casimiro DR. Analysis of plasmid DNA from a pharmaceutical perspective. J Pharm Sci 1998; 87:130-46.

11. Patel A, Walters J, Reuschel EL, et al. Intradermal-delivered DNA vaccine provides anamnestic protection in a rhesus macaque SARS-CoV-2 challenge model. bioRxiv 2020.

12. Gooch KE, Smith TRF, Salguero FJ, et al. One or two dose regimen of the SARS-CoV-2 synthetic DNA vaccine INO-4800 protects against respiratory tract disease burden in nonhuman primate challenge model. Vaccine 2021; 39:4885-94.

13. Walters JN, Schouest B, Patel A, et al. Prime-boost vaccination regimens with INO-4800 and INO4802 augment and broaden immune responses against SARS-CoV-2 in nonhuman primates. bioRxiv 2021:2021.10.27.466163.

14. Tebas $P$, Yang S, Boyer JD, et al. Safety and immunogenicity of INO-4800 DNA vaccine against SARSCoV-2: A preliminary report of an open-label, Phase 1 clinical trial. EClinicalMedicine 2021; 31:100689. 15. Mammen MP, Tebas P, Agnes J, et al. Safety and immunogenicity of INO-4800 DNA vaccine against SARS-CoV-2: a preliminary report of a randomized, blinded, placebo-controlled, Phase 2 clinical trial in adults at high risk of viral exposure. medRxiv : the preprint server for health sciences

2021:2021.05.07.21256652.

16. Tebas P, Roberts CC, Muthumani K, et al. Safety and Immunogenicity of an Anti-Zika Virus DNA Vaccine - Preliminary Report. N Engl J Med 2017.

17. Tebas $P$, Kraynyak KA, Patel A, et al. Intradermal SynCon(R) Ebola GP DNA Vaccine Is Temperature Stable and Safely Demonstrates Cellular and Humoral Immunogenicity Advantages in Healthy Volunteers. J Infect Dis 2019; 220:400-10.

18. Aggarwal C, Cohen RB, Morrow MP, et al. Immune Therapy Targeting E6/E7 Oncogenes of Human Paillomavirus Type 6 (HPV-6) Reduces or Eliminates the Need for Surgical Intervention in the Treatment of HPV-6 Associated Recurrent Respiratory Papillomatosis. Vaccines (Basel) 2020; 8.

19. Chen M, Yuan Y, Zhou Y, et al. Safety of SARS-CoV-2 vaccines: a systematic review and meta-analysis of randomized controlled trials. Infect Dis Poverty 2021; 10:94. 
medRxiv preprint doi: https://doi.org/10.1101/2021.10.06.21264584; this version posted January 25, 2022. The copyright holder for this preprint (which was not certified by peer review) is the author/funder, who has granted medRxiv a license to display the preprint in perpetuity.

All rights reserved. No reuse allowed without permission.

20. Wu Q, Dudley MZ, Chen X, et al. Evaluation of the safety profile of COVID-19 vaccines: a rapid review. BMC Med 2021; 19:173.

21. Siegrist CA, Aspinall R. B-cell responses to vaccination at the extremes of age. Nature reviews Immunology 2009; 9:185-94.

22. Prelog M. Differential approaches for vaccination from childhood to old age. Gerontology 2013; 59:230-9.

23. Kalimuddin S, Tham CYL, Qui M, et al. Early T cell and binding antibody responses are associated with COVID-19 RNA vaccine efficacy onset. Med (N Y) 2021; 2:682-8 e4.

24. Chen Z, John Wherry E. T cell responses in patients with COVID-19. Nature reviews Immunology 2020; 20:529-36.

25. Rydyznski Moderbacher C, Ramirez SI, Dan JM, et al. Antigen-Specific Adaptive Immunity to SARS-

CoV-2 in Acute COVID-19 and Associations with Age and Disease Severity. Cell 2020; 183:996-1012 e19.

26. Andrade VM, Christensen-Quick A, Agnes J, et al. INO-4800 DNA vaccine induces neutralizing antibodies and T cell activity against global SARS-CoV-2 variants. NPJ Vaccines 2021; 6:121. 
Table 1- Participant Demographics

\begin{tabular}{|c|c|c|c|c|c|}
\hline Variable & Statistic & $\begin{array}{l}0.5 \mathrm{mg} \\
(\mathrm{N}=40)\end{array}$ & $\begin{array}{l}1 \mathrm{mg} \\
(\mathrm{N}=40)\end{array}$ & $\begin{array}{l}2 \mathrm{mg} \\
(\mathrm{N}=40)\end{array}$ & $\begin{array}{l}\text { Total } \\
(\mathrm{N}=120)\end{array}$ \\
\hline \multicolumn{6}{|l|}{ Sex } \\
\hline Male & $\mathrm{n}(\%)$ & $18(45.0)$ & $17(42.5)$ & $16(40.0)$ & $51(42.5)$ \\
\hline Female & $\mathrm{n}(\%)$ & $22(55.0)$ & $23(57.5)$ & $24(60.0)$ & $69(57.5)$ \\
\hline \multicolumn{6}{|l|}{ Race } \\
\hline White & $\mathrm{n}(\%)$ & 40 (100) & $38(95.0)$ & $35(87.5)$ & $113(94.2)$ \\
\hline Black or African & $\mathrm{n}(\%)$ & 0 & $1(2.5)$ & $1(2.5)$ & $2(1.7)$ \\
\hline \multicolumn{6}{|l|}{ American } \\
\hline Asian & $\mathrm{n}(\%)$ & 0 & $1(2.5)$ & $4(10.0)$ & $5(4.2)$ \\
\hline \multicolumn{6}{|l|}{ Ethnicity } \\
\hline Hispanic or Latino & $\mathrm{n}(\%)$ & $3(7.5)$ & 0 & 0 & $3(2.5)$ \\
\hline $\begin{array}{l}\text { Not Hispanic or } \\
\text { Latino }\end{array}$ & n (\%) & $35(87.5)$ & $40(100)$ & $40(100)$ & $115(95.8)$ \\
\hline Not Reported & $\mathrm{n}(\%)$ & $2(5.0)$ & 0 & 0 & $2(1.7)$ \\
\hline \multirow[t]{4}{*}{ Age (years) } & $\mathrm{N}$ & 40 & 40 & 40 & 120 \\
\hline & Mean (SD) & $50.7(15.30)$ & $\begin{array}{l}49.2 \\
(16.75)\end{array}$ & $\begin{array}{l}50.7 \\
(17.90)\end{array}$ & $50.2(16.56)$ \\
\hline & Median & 52.5 & 51.0 & 50.5 & 50.5 \\
\hline & Min, Max & 23,76 & 18,73 & 19,86 & 18,86 \\
\hline
\end{tabular}


medRxiv preprint doi: https://doi.org/10.1101/2021.10.06.21264584; this version posted January 25, 2022. The copyright holder for this preprint (which was not certified by peer review) is the author/funder, who has granted medRxiv a license to display the preprint in perpetuity.

All rights reserved. No reuse allowed without permission.
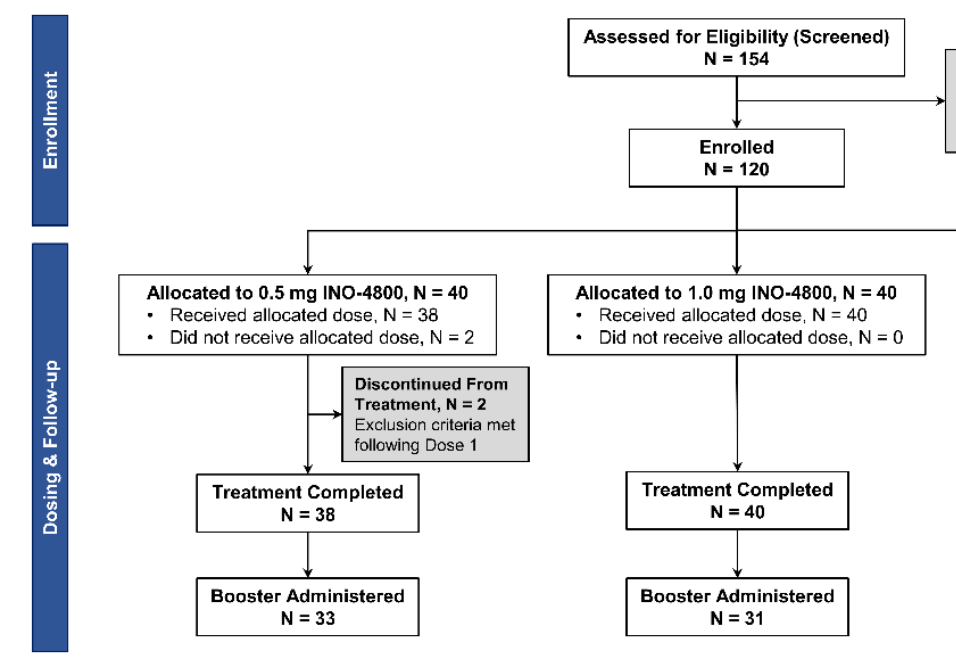

Excluded (Screen Failed), $\mathrm{N}=\mathbf{3 4}$

- Medical History, $\mathrm{N}=11$

- $\mathrm{BMI}, \mathrm{N}=7$

- Eligible not enrolled, $N=16$ 


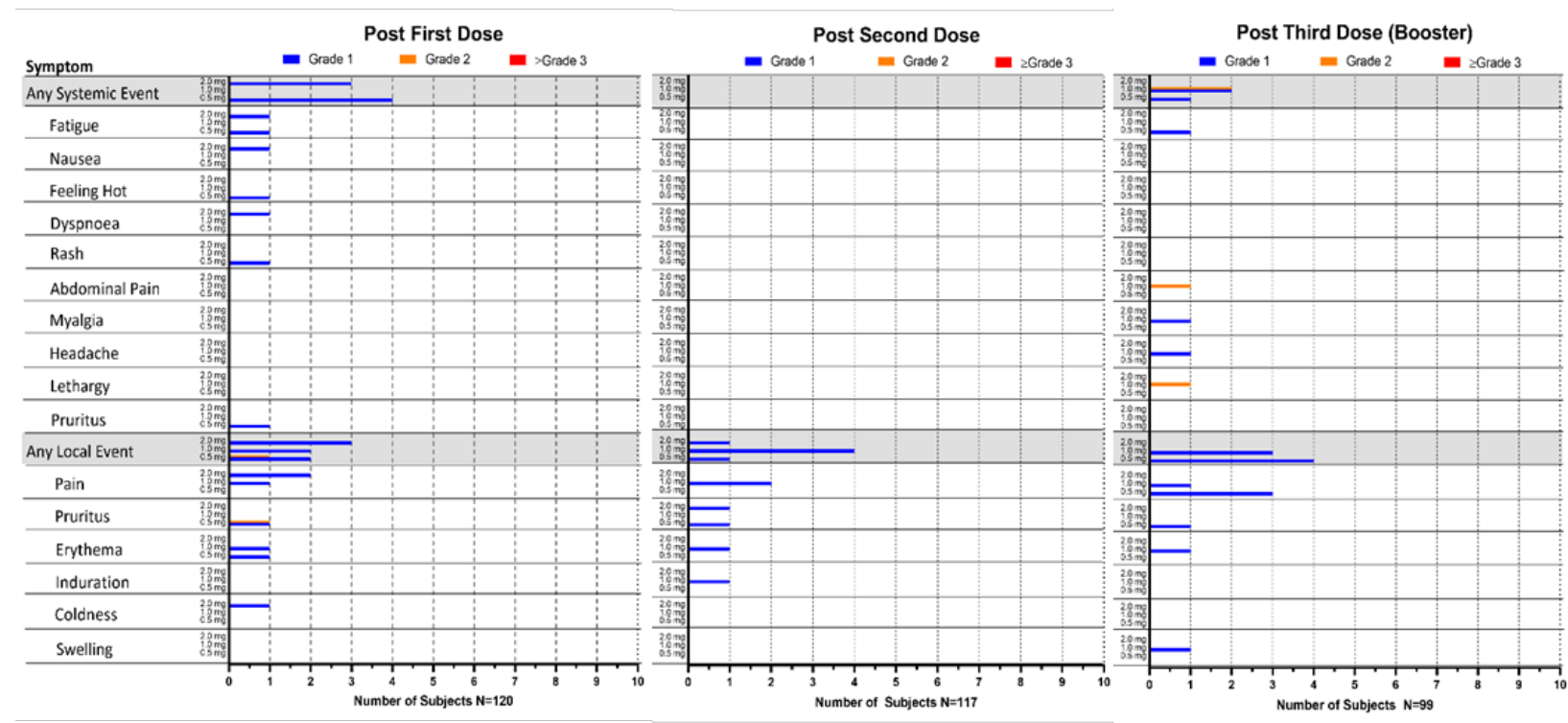

Figure 2- Related systemic and local adverse events. Post First Dose, $\mathrm{N}=120(\mathrm{~N}=40$ in each dose group), Post Second Dose, $\mathrm{N}=117$ ( $\mathrm{N}=38$ in the $0.5 \mathrm{mg}$ dose group, $\mathrm{N}=40$ in the $1.0 \mathrm{mg}$ dose group and $\mathrm{N}=39$ in the $2.0 \mathrm{mg}$ dose group, and Post Third Dose, $\mathrm{N}=99(\mathrm{~N}=33$ in the 0.5 mg dose group, $\mathrm{N}=31$ in the $1.0 \mathrm{mg}$ dose group and $\mathrm{N}=35 \mathrm{in}$ the $2.0 \mathrm{mg}$ dose group) 

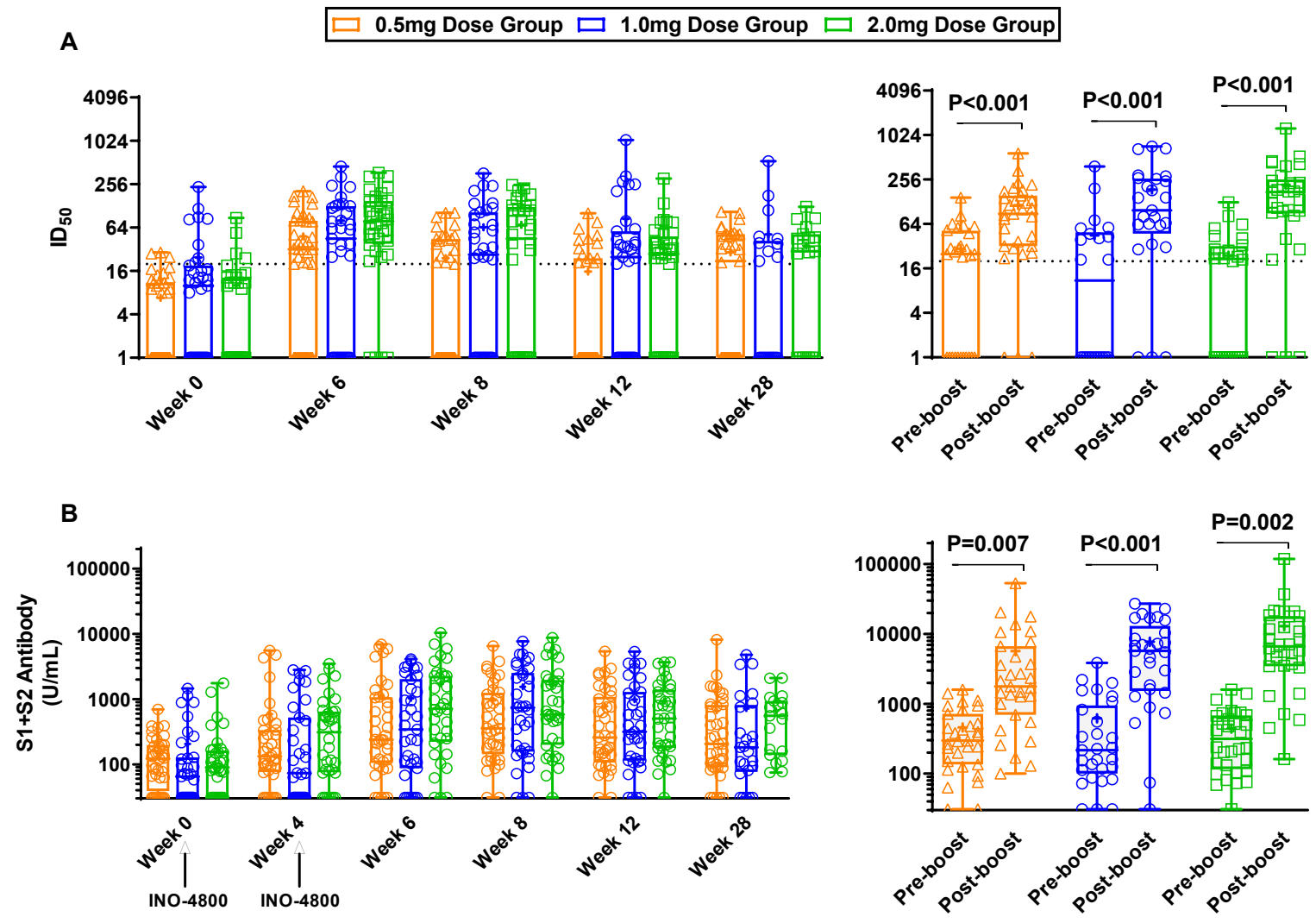

Figure 3- INO-4800 induces antibodies to SARS-CoV-2. A) Functional antibodies were assessed using a pseudovirus neutralization assay. The inhibition dilution where $50 \%$ neutralization occurs $\left(I_{50}\right)$ is plotted. The dotted line represents the lowest dilution tested in the assay (1:20). The left panel includes $n=40$ participants in the $0.5 \mathrm{mg}$ dose group, $n=35$ participants in the $1.0 \mathrm{mg}$ dose group and $\mathrm{n}=36$ participants in the $2.0 \mathrm{mg}$ dose group. The right panel includes $\mathrm{n}=33, \mathrm{n}=26$ and $\mathrm{n}=31$ participants in the $0.5 \mathrm{mg}, 1.0 \mathrm{mg}$, and $2.0 \mathrm{mg}$ dose groups, respectively. B) Binding antibody concentrations to the Spike trimer were measured using ELISA. The left panel includes $n=40$ participants in the $0.5 \mathrm{mg}$ dose group, $\mathrm{n}=35$ participants in the $1.0 \mathrm{mg}$ dose group and $n=36$ participants in the $2.0 \mathrm{mg}$ dose group. The right panel includes $n=31, n=29$ and $n=32$ participants in the $0.5 \mathrm{mg}, 1.0 \mathrm{mg}$, and $2.0 \mathrm{mg}$ dose groups, respectively. Open symbols represent individual participants, the box extends from the $25^{\text {th }}$ to the $75^{\text {th }}$ percentile, line inside the box is 
medRxiv preprint doi: https://doi.org/10.1101/2021.10.06.21264584; this version posted January 25, 2022. The copyright holder for this preprint (which was not certified by peer review) is the author/funder, who has granted medRxiv a license to display the preprint in perpetuity. All rights reserved. No reuse allowed without permission.

the median, and the whiskers extend from the minimum to maximum values. The mean is denoted with a "+" sign. Paired t test was used to assess significance versus baseline. The dose groups are represented by orange triangles $(0.5 \mathrm{mg})$, blue circles $(1.0 \mathrm{mg})$ and green squares $(2.0 \mathrm{mg})$. 


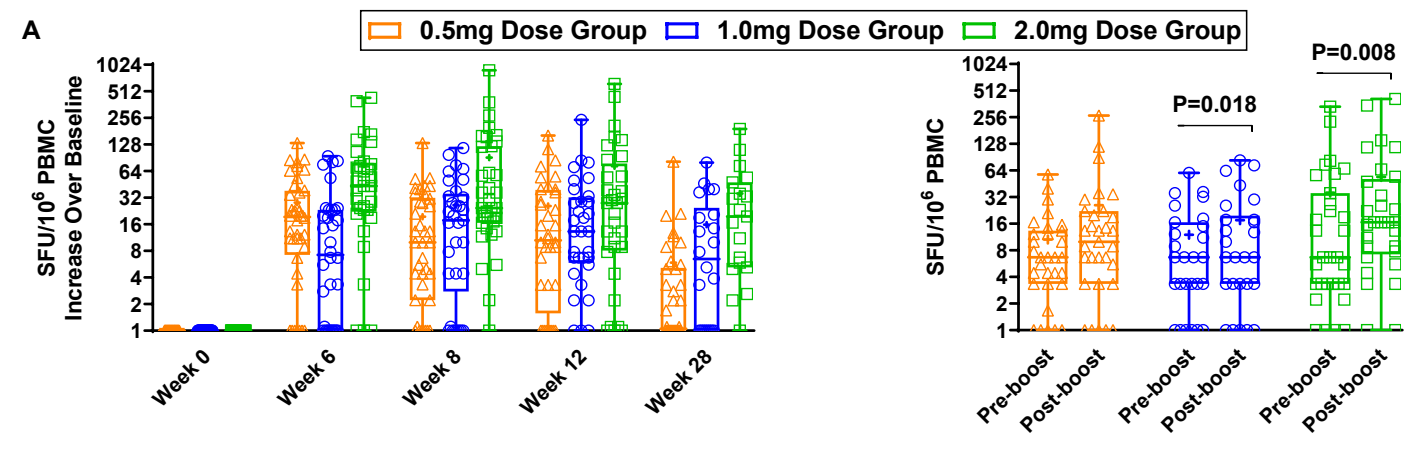

B

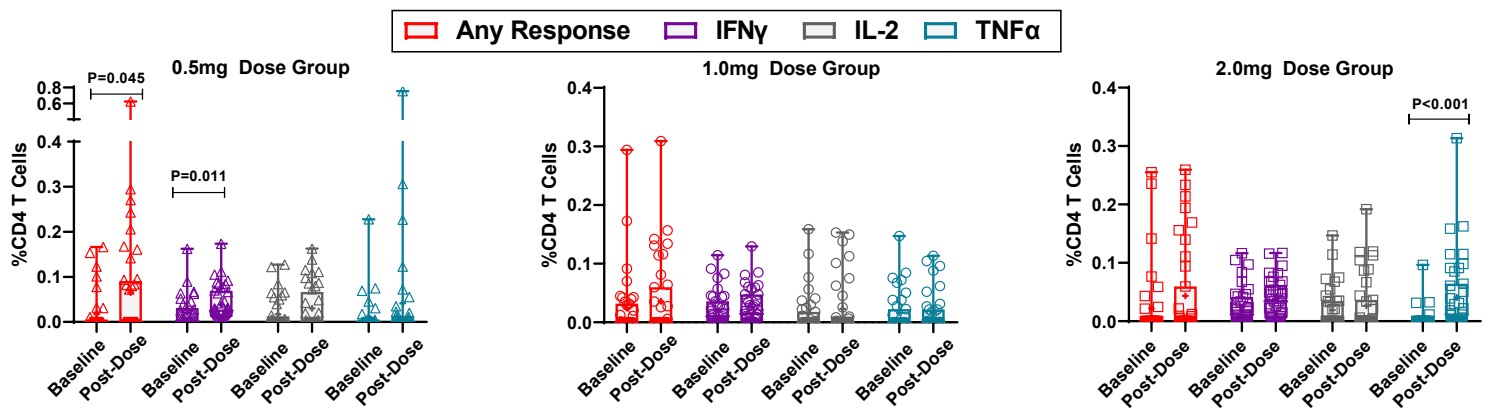

C
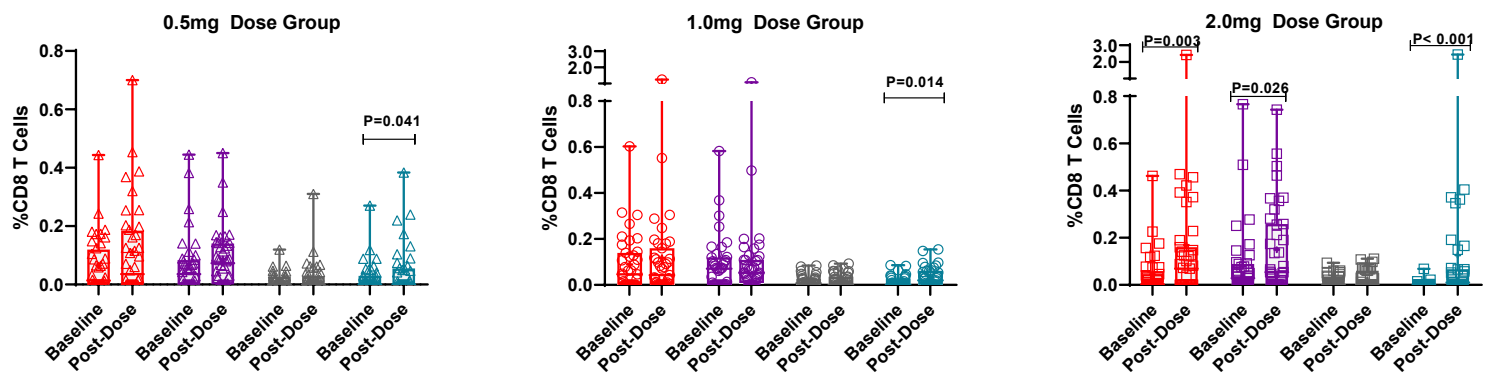

Figure 4- INO-4800 induces cellular responses to SARS-CoV-2 Spike. A) Longitudinal increases in spike antigen specific spot forming units per $10^{6}$ PBMCs over baseline in the IFN-g ELISpot are plotted. The left panel includes $\mathrm{n}=40$ participants in the $0.5 \mathrm{mg}$ dose group, $\mathrm{n}=35$ participants in the $1.0 \mathrm{mg}$ dose group and $\mathrm{n}=36$ participants in the $2.0 \mathrm{mg}$ dose group. The right panel includes $n=31, n=30$ and $n=34$ participants in the $0.5 \mathrm{mg}, 1.0 \mathrm{mg}$, and $2.0 \mathrm{mg}$ dose groups, respectively. B-C) Intracellular cytokine staining for IFN-g (purple) IL-2 (gray), TNF-a (blue) or any of the three cytokines (red) are plotted from samples collected at baseline or post-dose 2 . The graphs include $n=40$ participants in the $0.5 \mathrm{mg}$ dose group and $\mathrm{n}=39$ participants in the 1.0 $\mathrm{mg}$ and $2.0 \mathrm{mg}$ dose groups. Open symbols represent individual participants, the box extends from the $25^{\text {th }}$ to the $75^{\text {th }}$ percentile, line inside the box is the median, and the whiskers extend from 
medRxiv preprint doi: https://doi.org/10.1101/2021.10.06.21264584; this version posted January 25, 2022. The copyright holder for this preprint (which was not certified by peer review) is the author/funder, who has granted medRxiv a license to display the preprint in perpetuity. All rights reserved. No reuse allowed without permission.

the minimum to maximum values. The mean is denoted with a "+" sign. Wilcoxon signed-rank was used to assess significance versus baseline. The dose groups are represented by triangles $(0.5 \mathrm{mg})$, circles $(1.0 \mathrm{mg})$ and squares $(2.0 \mathrm{mg})$. 


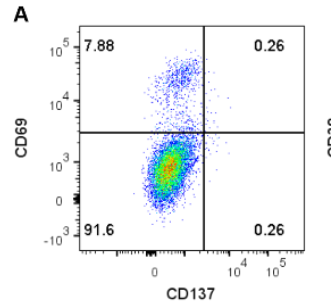

B

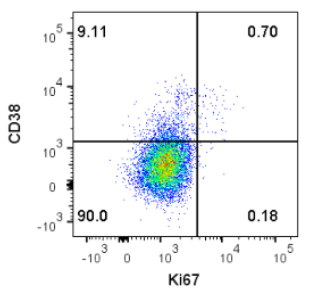

Ki67

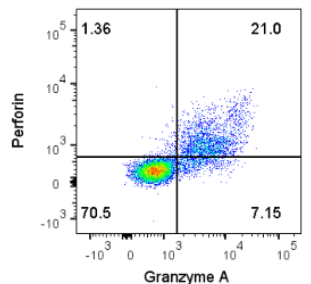

$1.0 \mathrm{mg}$ Dose Group
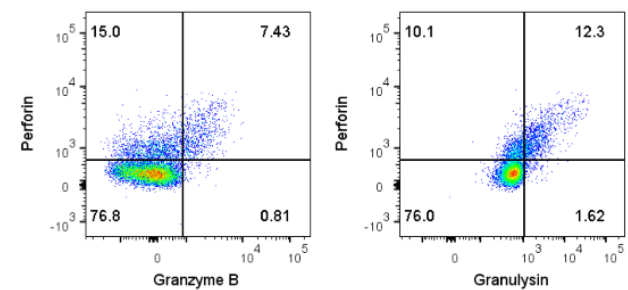

2.0mg Dose Group

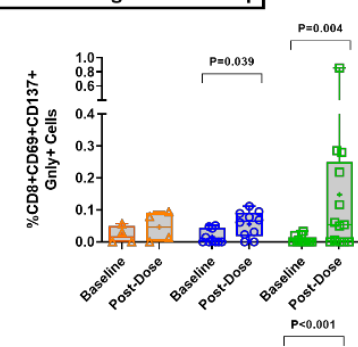

C
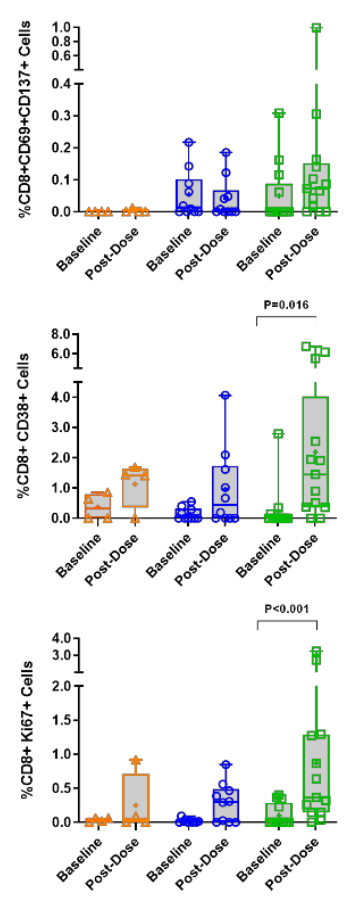
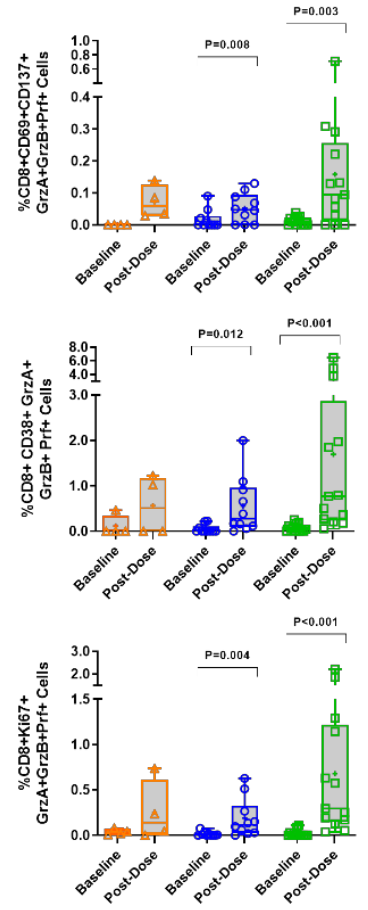
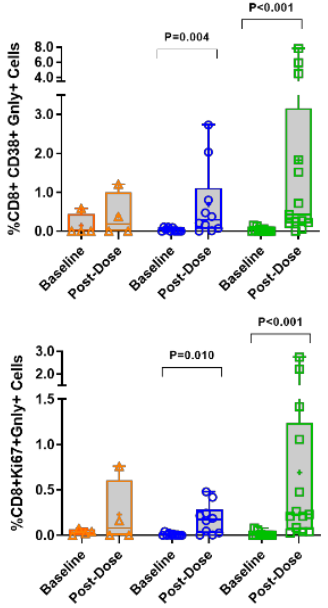

Figure 5- INO-4800 induces spike specific activated CD8+T cells with lytic potential. A lytic granule loading flow cytometry assay was used to further characterize CD8+T cells and an example gating strategy is shown in (A). The expression of the activation markers CD69 and CD137 (B), CD38 (C), and the proliferation marker Ki67 (D) from samples collected at baseline or post-dose 2. The expression of proteins found in lytic granules: granzymes $A(G r z A)$ and $B$ (GrzB), perforin (Prf) and granulysin (Gnly) were assessed together with activation/proliferation subset. The graphs include $n=4$ participants in the $0.5 \mathrm{mg}$ dose group and $n=10$ participants in the $1.0 \mathrm{mg}$ dose group and $\mathrm{n}=13 \mathrm{in}$ the $2.0 \mathrm{mg}$ dose group. Open symbols represent individual participants, the box extends from the $25^{\text {th }}$ to the $75^{\text {th }}$ percentile, line inside the box is the median, and the whiskers extend from the minimum to maximum values. The mean is denoted with a "+" 
medRxiv preprint doi: https://doi.org/10.1101/2021.10.06.21264584; this version posted January 25, 2022. The copyright holder for this preprint (which was not certified by peer review) is the author/funder, who has granted medRxiv a license to display the preprint in perpetuity.

All rights reserved. No reuse allowed without permission.

sign. Wilcoxon signed-rank was used to assess significance versus baseline. The dose groups are represented by orange triangles $(0.5 \mathrm{mg})$, blue circles $(1.0 \mathrm{mg})$ and green squares $(2.0 \mathrm{mg})$. 
medRxiv preprint doi: https://doi.org/10.1101/2021.10.06.21264584; this version posted January 25, 2022. The copyright holder for this preprint (which was not certified by peer review) is the author/funder, who has granted medRxiv a license to display the preprint in perpetuity.

All rights reserved. No reuse allowed without permission.

\section{Supplementary Methods}

\section{Study Design and Enrollment Progression}

Participants enrolled at one of three locations in the U.S.: The University of Pennsylvania Clinical Trials Unit in Philadelphia, PA; the Alliance for Multispecialty Research in Kansas City, $\mathrm{MO}$; and the Alliance for Multispecialty Research in Lexington, KY.

\section{Assessment of SARS-CoV-2 Specific Immune Responses}

\section{SARS-CoV-2 Spike Enzyme-Linked Immunosorbent Assay (ELISA) description: Costar high}

bind plates were coated by incubating $1-3$ days at $2-8^{\circ} \mathrm{C}$ with $2.0 \mu \mathrm{g} / \mathrm{mL}$ of recombinant SARS-

CoV-2 spike protein trimer (Acro Biosystems; SPN-C52H9) which contains amino acids 16-1213

of the original Wuhan-Hu-1 isolate spike protein (ascension\# QHD43416.1). The protein

contains six proline substitutions for trimer stabilization and two alanine substitutions to

eliminate the furin cleavage site. Coated plates were blocked with Starting Block (Thermo

Scientific), followed by the addition of study samples, diluted 1/20 in Starting Block buffer. Plates

were incubated for 1 hour, and then washed three times in PBS-tween. 1/1000-diluted anti-

human IgG HRP conjugate (BD Pharmingen; 555788) was added, and plates were incubated

for an additional hour. Plates were washed three times in PBS-tween, and SureBlue TMB

substrate (SeraCare) was added. Assay plates were developed for approximately 9 minutes,

and the color development was stopped by the addition of TMB Stop Solution (SeraCare).

SARS-CoV-2 spike antibody concentrations were assigned to study samples by interpolation

from a 4-parameter logistic model fit to a dilution curve of SARS-CoV-2 convalescent plasma.

The convalescent plasma reference material (Aalto Bio Reagents Ltd) collected from a single convalescent donor $>28$ days after symptom onset from a PCR-confirmed SARS-CoV-2 test was arbitrarily assigned a concentration of 20,000 Units per $\mathrm{mL}$. This sample was used as a control to standardize IgG responses across participant samples. 
medRxiv preprint doi: https://doi.org/10.1101/2021.10.06.21264584; this version posted January 25, 2022. The copyright holder for this preprint (which was not certified by peer review) is the author/funder, who has granted medRxiv a license to display the preprint in perpetuity.

\section{SARS-CoV-2 Pseudovirus Neutralization Assay}

Briefly, heat inactivated study serum samples were serially diluted and incubated for 90 minutes with a SARS-CoV-2-DeltaCT pseudovirus which is based on an HIV/luciferase reporter vector and expresses both SARS-CoV-2 spike protein and luciferase. After incubation, the pseudovirus/serum mixture was added to $\mathrm{CHO}$ target cells with stable ACE2 expression. After incubating the pseudovirus, serum, and cells together at $37^{\circ} \mathrm{C}$ for $72 \mathrm{~h}$, a britelite ${ }^{\mathrm{TM}}$ Plus luminescence reporter gene assay system (Perkin Elmer) was used to lyse cells and luminescence was measured using a Biotek plate reader.

\section{SARS-CoV-2 Spike ELISpot Assay Description}

Briefly, 300,000 peripheral mononuclear cells (PBMCs) per well were stimulated overnight in triplicate wells of a pre-coated IFN-y ELISpot plate (MabTech) using $200 \mathrm{ng}$ per peptide per well ( $1 \mu \mathrm{g} / \mathrm{mL}$ per peptide final concentration) of a single peptide pool consisting of 15 -mer peptides that overlapped by 9 residues and spanned the full-length spike protein. The next day, plates were developed as according to the manufacturer's instructions (MabTech, Human IFN-g ELISpot Plus). A CTL S6 Micro Analyzer (CTL) with ImmunoCapture and ImmunoSpot software was used to scan and count spots corresponding to IFN-y secreting cells. The ELISpot assay was performed in several batches due to the longevity of the study- the week 0 timepoint is run with each post-dose batch in order to have an appropriate baseline control. To most accurately represent the data, the baseline sample is subtracted from the post dose sample run in the same batch. The average of all week 0 values is $8.2 \mathrm{SFU} / 10^{6}$ and the median is $3.3 \mathrm{SFU} / 10^{6}$. 


\section{Supplementary Data}

Supplementary Table 1: Geometric Mean Titers (GMT) in the pseudovirus neutralization assay

\begin{tabular}{|c|c|c|c|c|c|c|c|c|c|c|c|c|c|c|}
\hline \multirow[b]{2}{*}{$\begin{array}{l}\text { Dose } \\
\text { Group }\end{array}$} & \multicolumn{2}{|c|}{ Week 0} & \multicolumn{3}{|c|}{ Week 6} & \multicolumn{3}{|c|}{ Week 8} & \multicolumn{3}{|c|}{ Week 12} & \multicolumn{3}{|c|}{ Week 28} \\
\hline & $\mathbf{N}$ & $\begin{array}{c}\text { GMT } \\
(95 \% \mathrm{Cl})\end{array}$ & $\mathbf{N}$ & $\begin{array}{c}\text { GMT } \\
(95 \% \mathrm{Cl})\end{array}$ & $\begin{array}{c}\mathbf{P} \\
\text { value }\end{array}$ & $\mathbf{N}$ & $\begin{array}{c}\text { GMT } \\
(95 \% \mathrm{CI})\end{array}$ & $\begin{array}{c}P \\
\text { value }\end{array}$ & $\mathbf{N}$ & $\begin{array}{c}\text { GMT } \\
(95 \% \mathrm{Cl})\end{array}$ & $\begin{array}{c}\mathbf{P} \\
\text { value }\end{array}$ & $\mathbf{N}$ & $\begin{array}{c}\text { GMT } \\
(95 \% \mathrm{CI})\end{array}$ & $\begin{array}{c}P \\
\text { value }\end{array}$ \\
\hline $\begin{array}{l}0.5 \\
\mathrm{mg}\end{array}$ & 40 & $\begin{array}{c}3.01 \\
(1.97, \\
4.60)\end{array}$ & 40 & $\begin{array}{l}14.94 \\
(7.90 \\
28.25)\end{array}$ & $<0.001$ & 40 & $\begin{array}{c}\mathbf{6 . 0 0} \\
(3.23 \\
11.17)\end{array}$ & $<0.001$ & 39 & $\begin{array}{c}3.65 \\
(1.00 \\
101.0)\end{array}$ & 0.018 & 35 & $\begin{array}{c}\mathbf{8 . 1 7} \\
(1.00 \\
106.0)\end{array}$ & $<0.001$ \\
\hline $\begin{array}{l}1.0 \\
\mathrm{mg}\end{array}$ & 35 & $\begin{array}{c}\mathbf{6 . 1 8} \\
(1.00 \\
235.0)\end{array}$ & 35 & $\begin{array}{c}19.07 \\
(8.79 \\
41.37)\end{array}$ & 0.003 & 35 & $\begin{array}{l}14.79 \\
(6.93 \\
31.55)\end{array}$ & 0.005 & 35 & $\begin{array}{l}12.50 \\
(5.75 \\
27.19)\end{array}$ & 0.023 & 21 & $\begin{array}{c}7.00 \\
(2.57 \\
19.03)\end{array}$ & 0.308 \\
\hline $\begin{array}{l}2.0 \\
\mathrm{mg}\end{array}$ & 36 & $\begin{array}{c}3.50 \\
(2.12, \\
5.78)\end{array}$ & 36 & $\begin{array}{c}54.15 \\
(31.46 \\
93.21)\end{array}$ & $<0.001$ & 36 & $\begin{array}{l}16.13 \\
(7.39 \\
35.23)\end{array}$ & $<0.001$ & 36 & $\begin{array}{l}11.37 \\
(5.93 \\
21.80)\end{array}$ & 0.009 & 19 & $\begin{array}{l}11.87 \\
(4.58 \\
30.76)\end{array}$ & 0.036 \\
\hline
\end{tabular}

$\mathrm{P}$ values compare titers at each study week with those at Week 0

\begin{tabular}{|c|c|c|c|c|}
\hline \multirow{2}{*}{$\begin{array}{l}\text { Dose } \\
\text { Group }\end{array}$} & \multicolumn{2}{|c|}{ Pre-boost } & \multicolumn{2}{|c|}{ Post-boost } \\
\hline & $\mathbf{N}$ & GMT (95\% Cl) & $\mathbf{N}$ & GMT (95\% Cl) \\
\hline $0.5 \mathrm{mg}$ & 28 & $9.6(4.6,20.02)$ & 31 & $58.73(32.92,104.75)$ \\
\hline $1.0 \mathrm{mg}$ & 22 & $7.61(2.92,19.84)$ & 25 & $76.12(35.18,164.69)$ \\
\hline $2.0 \mathrm{mg}$ & 28 & $7.65(3.75,15.62)$ & 30 & $100.0(51.46,194.33)$ \\
\hline
\end{tabular}


Supplementary Table 2: Geometric Mean Titers (GMT) in ELISA

\begin{tabular}{|c|c|c|c|c|c|c|c|c|c|c|c|c|c|c|c|c|c|}
\hline \multirow[b]{2}{*}{$\begin{array}{l}\text { Dose } \\
\text { Group }\end{array}$} & \multicolumn{2}{|c|}{ Week 0} & \multicolumn{3}{|c|}{ Week 4} & \multicolumn{3}{|c|}{ Week 6} & \multicolumn{3}{|c|}{ Week 8} & \multicolumn{3}{|c|}{ Week 12} & \multicolumn{3}{|c|}{ Week 28} \\
\hline & $\mathbf{N}$ & $\begin{array}{c}\text { GMT } \\
(95 \% \\
\text { CI) }\end{array}$ & $\mathbf{N}$ & $\begin{array}{c}\text { GMT } \\
(95 \% \\
\text { CI) }\end{array}$ & $\begin{array}{c}P \\
\text { value }\end{array}$ & $\mathbf{N}$ & $\begin{array}{c}\text { GMT } \\
(95 \% \mathrm{Cl})\end{array}$ & $\begin{array}{c}\text { P } \\
\text { value }\end{array}$ & $\mathbf{N}$ & $\begin{array}{c}\text { GMT } \\
(95 \% \mathrm{CI})\end{array}$ & $\begin{array}{c}P \\
\text { value }\end{array}$ & $\mathbf{N}$ & $\begin{array}{c}\text { GMT } \\
(95 \% \\
\text { CI) }\end{array}$ & $\begin{array}{c}P \\
\text { value }\end{array}$ & $\mathbf{N}$ & $\begin{array}{c}\text { GMT } \\
(95 \% \\
\text { CI) }\end{array}$ & $\begin{array}{c}P \\
\text { value }\end{array}$ \\
\hline $\begin{array}{l}0.5 \\
\mathrm{mg}\end{array}$ & 40 & $\begin{array}{c}103.55 \\
(78.0 \\
137.46)\end{array}$ & 40 & $\begin{array}{r}173.47 \\
(110.93, \\
271.25) \\
\end{array}$ & 0.035 & 40 & $\begin{array}{r}333.54 \\
(201.16 \\
553.02) \\
\end{array}$ & 0.002 & 40 & $\begin{array}{r}\mathbf{4 2 8 . 4 5} \\
(279.42 \\
656.97) \\
\end{array}$ & $<0.001$ & 40 & $\begin{array}{r}330.47 \\
(214.29 \\
509.66) \\
\end{array}$ & 0.001 & 40 & $\begin{array}{r}\mathbf{2 5 0 . 0 8} \\
(160.91 \\
388.67) \\
\end{array}$ & 0.019 \\
\hline $\begin{array}{l}1.0 \\
\mathrm{mg}\end{array}$ & 35 & $\begin{array}{c}\mathbf{8 3 . 5} \\
(55.04 \\
126.7) \\
\end{array}$ & 35 & $\begin{array}{l}133.89 \\
(76.13, \\
235.47) \\
\end{array}$ & 0.007 & 35 & $\begin{array}{c}337.78 \\
(187.26 \\
609.28) \\
\end{array}$ & $<0.001$ & 35 & $\begin{array}{c}\mathbf{5 9 5 . 9 5} \\
(343.01 \\
1035.40)\end{array}$ & $<0.001$ & 35 & $\begin{array}{r}371.23 \\
(220.08, \\
626.19) \\
\end{array}$ & $<0.001$ & 25 & $\begin{array}{c}\mathbf{2 1 5 . 2 6} \\
(113.62, \\
407.82) \\
\end{array}$ & 0.026 \\
\hline $\begin{array}{l}2.0 \\
\mathrm{mg}\end{array}$ & 36 & $\begin{array}{c}100.69 \\
(70.9 \\
143.01)\end{array}$ & 36 & $\begin{array}{c}236.7 \\
(144.59, \\
387.48)\end{array}$ & 0.004 & 36 & $\begin{array}{c}\mathbf{6 5 3 . 5 9} \\
(380.01 \\
1124.13) \\
\end{array}$ & $<0.001$ & 36 & $\begin{array}{r}\mathbf{6 7 7 . 9 7} \\
(414.95 \\
1107.72) \\
\end{array}$ & $<0.001$ & 36 & $\begin{array}{r}468.35 \\
(305.26 \\
718.57) \\
\end{array}$ & $<0.001$ & 19 & $\begin{array}{r}407.15 \\
(239.95 \\
690.85) \\
\end{array}$ & 0.012 \\
\hline
\end{tabular}

$\mathrm{P}$ values compare titers at each study week with those at Week 0

\begin{tabular}{|c|c|c|c|c|}
\hline \multirow{2}{*}{$\begin{array}{c}\text { Dose } \\
\text { Group }\end{array}$} & $\mathbf{N}$ & Pre-boost & $\mathbf{N}$ & Post-boost \\
\cline { 2 - 5 } & GMT (95\% Cl) & 31 & GMT (95\% Cl) \\
\hline $0.5 \mathrm{mg}$ & 31 & $\mathbf{2 9 2 . 6 5}(199.21,429.93)$ & 29 & $\mathbf{1 9 6 3 . 7 7}(1111.61,3469.2)$ \\
\hline $1.0 \mathrm{mg}$ & 29 & $\mathbf{2 6 1 . 7 1}(156.33,438.14)$ & 32 & $\mathbf{3 6 8 5 . 4 9}(1992.72,6816.2)$ \\
\hline $2.0 \mathrm{mg}$ & 32 & $\mathbf{2 8 5 . 9 1}(198.45,411.91)$ & $\mathbf{5 9 5 3 . 1 4}(3616.44,9799.6)$ \\
\hline
\end{tabular}


Supplementary Table 3: Spike-specific SFU $/ 10^{6}$ PBMCs in the IFN- $\gamma$ ELISpot assay

\begin{tabular}{|c|c|c|c|c|c|c|c|c|}
\hline \multirow[b]{2}{*}{$\begin{array}{l}\text { Dose } \\
\text { Group }\end{array}$} & \multicolumn{2}{|r|}{ Week 6} & \multicolumn{2}{|r|}{ Week 8} & \multicolumn{2}{|r|}{ Week 12} & \multicolumn{2}{|r|}{ Week 28} \\
\hline & $\mathbf{N}$ & $\begin{array}{c}\text { Median SFU } / 10^{6} \\
\text { PBMCs } \\
(95 \% \mathrm{Cl})\end{array}$ & $\mathbf{N}$ & $\begin{array}{c}\text { Median SFU } / 10^{6} \\
\text { PBMCs } \\
(95 \% \mathrm{Cl})\end{array}$ & $\mathbf{N}$ & $\begin{array}{c}\text { Median SFU } / 10^{6} \\
\text { PBMCs } \\
(95 \% \mathrm{Cl})\end{array}$ & $\mathbf{N}$ & $\begin{array}{c}\text { Median SFU } / 10^{6} \\
\text { PBMCs } \\
(95 \% \mathrm{Cl})\end{array}$ \\
\hline $0.5 \mathrm{mg}$ & 40 & $\begin{array}{c}19.4 \\
(11.1,23.3)\end{array}$ & 38 & $\begin{array}{c}10.0 \\
(4.4,25.6)\end{array}$ & 36 & $\begin{array}{c}10.6 \\
(6.7,26.7)\end{array}$ & 38 & $\begin{array}{c}1.1 \\
(1.0,3.3)\end{array}$ \\
\hline $1.0 \mathrm{mg}$ & 34 & $\begin{array}{c}7.2 \\
(2.8,20.0)\end{array}$ & 33 & $\begin{array}{c}17.8 \\
(4.4,27.8)\end{array}$ & 32 & $\begin{array}{c}13.3 \\
(6.7,28.9)\end{array}$ & 22 & $\begin{array}{c}\mathbf{6 . 5} \\
(1.0,20.6)\end{array}$ \\
\hline $2.0 \mathrm{mg}$ & 33 & $\begin{array}{c}43.3 \\
(24.4,70.0)\end{array}$ & 35 & $\begin{array}{c}24.4 \\
(18.9,57.8)\end{array}$ & 32 & $\begin{array}{c}\mathbf{2 7 . 8} \\
(11.1,54.4)\end{array}$ & 19 & $\begin{array}{c}19.6 \\
(5.9,47.8)\end{array}$ \\
\hline
\end{tabular}

Median of background subtracted magnitudes

$95 \% \mathrm{Cl}=95 \%$ Non-parametric confidence intervals for the median

\begin{tabular}{|c|c|c|c|c|}
\hline \multirow{2}{*}{$\begin{array}{l}\text { Dose } \\
\text { Group }\end{array}$} & \multicolumn{2}{|r|}{ Pre-boost } & \multicolumn{2}{|r|}{ Post-boost } \\
\hline & $\mathbf{N}$ & Median SFU/10 6 PBMCs (95\% Cl) & $\mathbf{N}$ & Median SFU/10 6 PBMCs (95\% Cl) \\
\hline $0.5 \mathrm{mg}$ & 31 & $6.7(4.4,12.2)$ & 31 & $10.0(6.7,18.9)$ \\
\hline $1.0 \mathrm{mg}$ & 29 & $6.7(3.3,12.2)$ & 28 & $8.3(3.3,17.8)$ \\
\hline $2.0 \mathrm{mg}$ & 33 & $6.7(3.3,22.2)$ & 31 & $16.7(8.9,47.8)$ \\
\hline
\end{tabular}

$95 \% \mathrm{Cl}=95 \%$ Non-parametric confidence intervals for the median 
medRxiv preprint doi: https://doi.org/10.1101/2021.10.06.21264584; this version posted January 25, 2022. The copyright holder for this preprint (which was not certified by peer review) is the author/funder, who has granted medRxiv a license to display the preprint in perpetuity.

Supplementary Table 4: Summary of treatment-related Adverse Events by Age, Term, and Dose: Treatment related AEs were reported by A) twelve 18-50 year old participants (20\%) reported B) five 51-64 year old participants (16.7\%) and C) one $\geq 65$ year old participant (3.3\%). All AEs were Grade 1 (mild) in severity with the exception of Grade 2 (moderate) lethargy, abdominal pain, and injection site pruritus. In case of multiple events, a participant is counted only once per system organ class and once per preferred term.

A)

\begin{tabular}{|c|c|c|c|c|}
\hline \multirow{2}{*}{$\begin{array}{l}\text { System Organ } \\
\text { Class Preferred } \\
\text { Term }\end{array}$} & \multicolumn{4}{|c|}{$18-50$ Years, n (\%) } \\
\hline & $\begin{array}{c}\text { INO-4800 } \\
0.5 \mathrm{mg}(\mathrm{N}=20)\end{array}$ & $\begin{array}{c}\text { INO-4800 } \\
1.0 \mathrm{mg}(\mathrm{N}=20)\end{array}$ & $\begin{array}{c}\text { INO-4800 } \\
2.0 \mathrm{mg}(\mathrm{N}=20)\end{array}$ & Total $(\mathrm{N}=60)$ \\
\hline $\begin{array}{l}\text { At least one related } \\
\text { TEAE }\end{array}$ & $6(30.0)$ & $4(20.0)$ & $2(10.0)$ & $12(20.0)$ \\
\hline $\begin{array}{l}\text { General disorders } \\
\text { and administration } \\
\text { site conditions }\end{array}$ & $6(30.0)$ & $4(20.0)$ & $1(5.0)$ & $11(18.3)$ \\
\hline $\begin{array}{l}\text { Injection site } \\
\text { erythema }\end{array}$ & $1(5.0)$ & $3(15.0)$ & 0 & $4(6.7)$ \\
\hline Injection site pain & $2(10.0)$ & $2(10.0)$ & $1(5.0)$ & $5(8.3)$ \\
\hline $\begin{array}{l}\text { Injection site } \\
\text { pruritus }\end{array}$ & $3(15.0)$ & 0 & 0 & $3(5.0)$ \\
\hline Fatigue & $1(5.0)$ & 0 & 0 & $1(1.7)$ \\
\hline Feeling hot & $1(5.0)$ & 0 & 0 & $1(1.7)$ \\
\hline $\begin{array}{l}\text { Injection site } \\
\text { swelling }\end{array}$ & 0 & $1(5.0)$ & 0 & $1(1.7)$ \\
\hline $\begin{array}{l}\text { Gastrointestinal } \\
\text { disorders }\end{array}$ & 0 & $1(5.0)$ & $1(5.0)$ & $2(3.3)$ \\
\hline $\begin{array}{l}\text { Abdominal pain } \\
\text { upper }\end{array}$ & 0 & $1(5.0)$ & 0 & $1(1.7)$ \\
\hline Nausea & 0 & 0 & $1(5.0)$ & $1(1.7)$ \\
\hline $\begin{array}{l}\text { Musculoskeletal } \\
\text { disorders }\end{array}$ & 0 & $1(5.0)$ & 0 & $1(1.7)$ \\
\hline Myalgia & 0 & $1(5.0)$ & 0 & $1(1.7)$ \\
\hline $\begin{array}{l}\text { Nervous system } \\
\text { disorders }\end{array}$ & 0 & $1(5.0)$ & 0 & $1(1.7)$ \\
\hline Headache & 0 & $1(5.0)$ & 0 & $1(1.7)$ \\
\hline Lethargy & 0 & $1(5.0)$ & 0 & $1(1.7)$ \\
\hline $\begin{array}{l}\text { Skin and } \\
\text { subcutaneous } \\
\text { tissue disorders }\end{array}$ & $1(5.0)$ & 0 & 0 & $1(1.7)$ \\
\hline Pruritus & $1(5.0)$ & 0 & 0 & $1(1.7)$ \\
\hline Rash & $1(5.0)$ & 0 & 0 & $1(1.7)$ \\
\hline
\end{tabular}


B)

\begin{tabular}{|c|c|c|c|c|}
\hline \multirow{2}{*}{$\begin{array}{l}\text { System Organ } \\
\text { Class Preferred } \\
\text { Term }\end{array}$} & \multicolumn{4}{|c|}{ 51-64 Years, n (\%) } \\
\hline & $\begin{array}{c}\text { INO-4800 } \\
0.5 \mathrm{mg}(\mathrm{N}=10)\end{array}$ & $\begin{array}{c}\text { INO-4800 } \\
1.0 \mathrm{mg}(\mathrm{N}=10)\end{array}$ & $\begin{array}{c}\text { INO-4800 } \\
2.0 \mathrm{mg}(\mathrm{N}=10)\end{array}$ & Total $(\mathrm{N}=30)$ \\
\hline $\begin{array}{l}\text { At least one } \\
\text { related TEAE }\end{array}$ & 0 & $2(20.0)$ & $3(30.0)$ & 5 (16.7) \\
\hline $\begin{array}{l}\text { General disorders } \\
\text { and } \\
\text { administration site } \\
\text { conditions }\end{array}$ & 0 & $2(20.0)$ & $3(30.0)$ & $5(16.7)$ \\
\hline Injection site pain & 0 & $1(10.0)$ & $1(10.0)$ & $2(6.7)$ \\
\hline $\begin{array}{l}\text { Injection site } \\
\text { pruritus }\end{array}$ & 0 & 0 & $1(10.0)$ & $1(3.3)$ \\
\hline $\begin{array}{l}\text { Injection site } \\
\text { induration }\end{array}$ & 0 & $1(10.0)$ & 0 & $1(3.3)$ \\
\hline $\begin{array}{l}\text { Injection site } \\
\text { coldness }\end{array}$ & 0 & 0 & $1(10.0)$ & $1(3.3)$ \\
\hline Fatigue & 0 & 0 & $1(10.0)$ & $1(3.3)$ \\
\hline $\begin{array}{l}\text { Respiratory, } \\
\text { thoracic, and } \\
\text { mediastinal } \\
\text { disorders }\end{array}$ & 0 & 0 & $1(10.0)$ & $1(3.3)$ \\
\hline Dyspnea & 0 & 0 & $1(10.0)$ & $1(3.3)$ \\
\hline
\end{tabular}

C)

\begin{tabular}{|l|c|c|c|c|}
\hline \multirow{2}{*}{$\begin{array}{l}\text { System Organ } \\
\text { Class Preferred } \\
\text { Term }\end{array}$} & \multicolumn{4}{|c|}{$\geq 65$ Years, $\mathrm{n}(\%)$} \\
\cline { 2 - 5 } & $\begin{array}{c}\mathrm{INO}-4800 \\
\mathbf{0 . 5} \mathrm{mg} \mathrm{(N=10)}\end{array}$ & $\begin{array}{c}\text { INO-4800 } \\
1.0 \mathrm{mg}(\mathrm{N}=10)\end{array}$ & $\begin{array}{c}\text { INO-4800 } \\
2.0 \mathrm{mg}(\mathrm{N}=10)\end{array}$ & Total (N=30) \\
\hline $\begin{array}{l}\text { At least one } \\
\text { related TEAE }\end{array}$ & $1(10.0)$ & 0 & 0 & $1(3.3)$ \\
\hline $\begin{array}{l}\text { General disorders } \\
\text { and } \\
\text { administration site } \\
\text { conditions }\end{array}$ & $1(10.0)$ & 0 & 0 & $1(3.3)$ \\
\hline \multicolumn{1}{|l|}{ Injection site pain } & $1(10.0)$ & 0 & 0 & $1(3.3)$ \\
\hline
\end{tabular}


medRxiv preprint doi: https://doi.org/10.1101/2021.10.06.21264584; this version posted January 25, 2022. The copyright holder for this preprint (which was not certified by peer review) is the author/funder, who has granted medRxiv a license to display the preprint in perpetuity.

All rights reserved. No reuse allowed without permission.

\section{Supplementary Figure 1: INO-4800 induces antibodies to SARS-CoV-2 across all age groups $18-50,51-64$ and $\geq 65$ year olds}

A) Functional antibodies were assessed using a pseudovirus neutralization assay. The inhibition dilution where $50 \%$ neutralization occurs $\left(I D_{50}\right)$ is plotted. The left panel includes $n=40$ participants in the $0.5 \mathrm{mg}$ dose group ( $\mathrm{n}=2018-50$ year olds, $n=1051-64$ year olds and $n=10 \geq 65$ year olds), $n=35$ participants in the $1.0 \mathrm{mg}$ dose group $(n=1718-50$ year olds, $n=951-64$ year olds and $n=9$ $\geq 65$ year olds) and $n=36$ participants in the $2.0 \mathrm{mg}$ dose group $(n=1818-50$ year olds, $n=8$ 51-64 year olds and $n=10 \geq 65$ year olds). The right panel includes only participants with paired data available $n=26(n=12$ 18-50 year olds, $n=9$ 51-64 year olds and $n=5 \geq 65$ year olds), $n=21(n=11$ 18-50 year olds, $n=6,51-64$ year olds and $n=4 \geq 65$ year olds) and $n=27$ ( $n=1518-50$ year olds, $\mathrm{n}=551-64$ year olds and $\mathrm{n}=7 \geq 65$ year olds) participants in the $0.5 \mathrm{mg}, 1.0 \mathrm{mg}$, and $2.0 \mathrm{mg}$ dose groups, respectively.

B) Binding antibody concentrations to the Spike trimer were measured using ELISA. The left panel includes $n=40$ participants in the $0.5 \mathrm{mg}$ dose group $(\mathrm{n}=2018-50$ year olds, $n=10$ 51-64 year olds and $n=10 \geq 65$ year olds) , $n=35$ participants in the 1.0 mg dose group ( $n=17$ 18-50 year olds, $n=9$ 51-64 year olds and $n=9 \geq 65$ year olds) and $n=36$ participants in the 2.0 mg dose group ( $n=18$ 18-50 year olds, $n=8$ 51-64 year olds and $n=10 \geq 65$ year olds). The right panel includes only participants with paired data available $n=31(n=16$ 18-50 year olds, $n=8$ 51-64 year olds and $n=7$ $\geq 65$ year olds), $n=29$ ( $n=1318-50$ year olds, $n=8,51-64$ year olds and $n=8 \geq 65$ year olds) and $n=32$ ( $n=1518-50$ year olds, $n=751-64$ year olds and $n=10 \geq 65$ year olds) participants in the 0.5 $\mathrm{mg}, 1.0 \mathrm{mg}$, and $2.0 \mathrm{mg}$ dose groups, respectively. Open symbols represent individual participants, the horizontal line represents the GMT and the whiskers extend to the $95 \% \mathrm{Cl}$ values. Paired t test was used to assess significance versus baseline. The dose groups are represented by orange triangles $(0.5 \mathrm{mg})$, blue circles $(1.0 \mathrm{mg})$ and green squares $(2.0 \mathrm{mg})$. 
A

18-50 year olds

51-64 year olds $\begin{array}{r}1024 \\ 256 \\ O\end{array}$

$\geq 65$ year olds

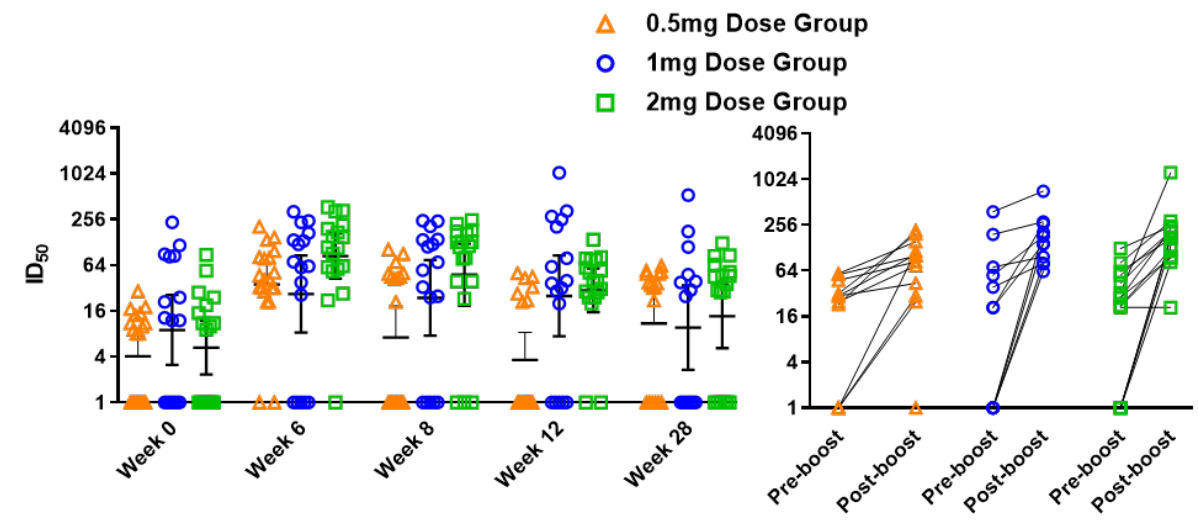

$\Delta \quad 0.5 \mathrm{mg}$ Dose Group

- $1 \mathrm{mg}$ Dose Group
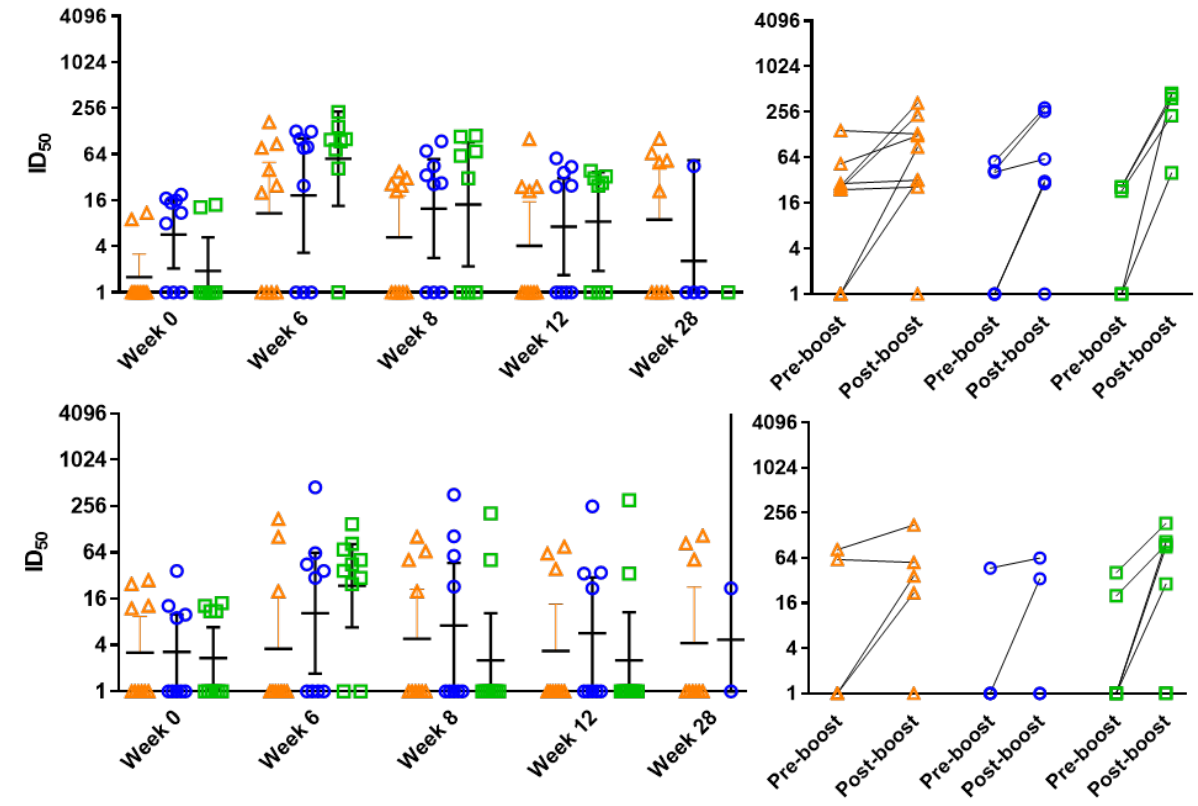
B
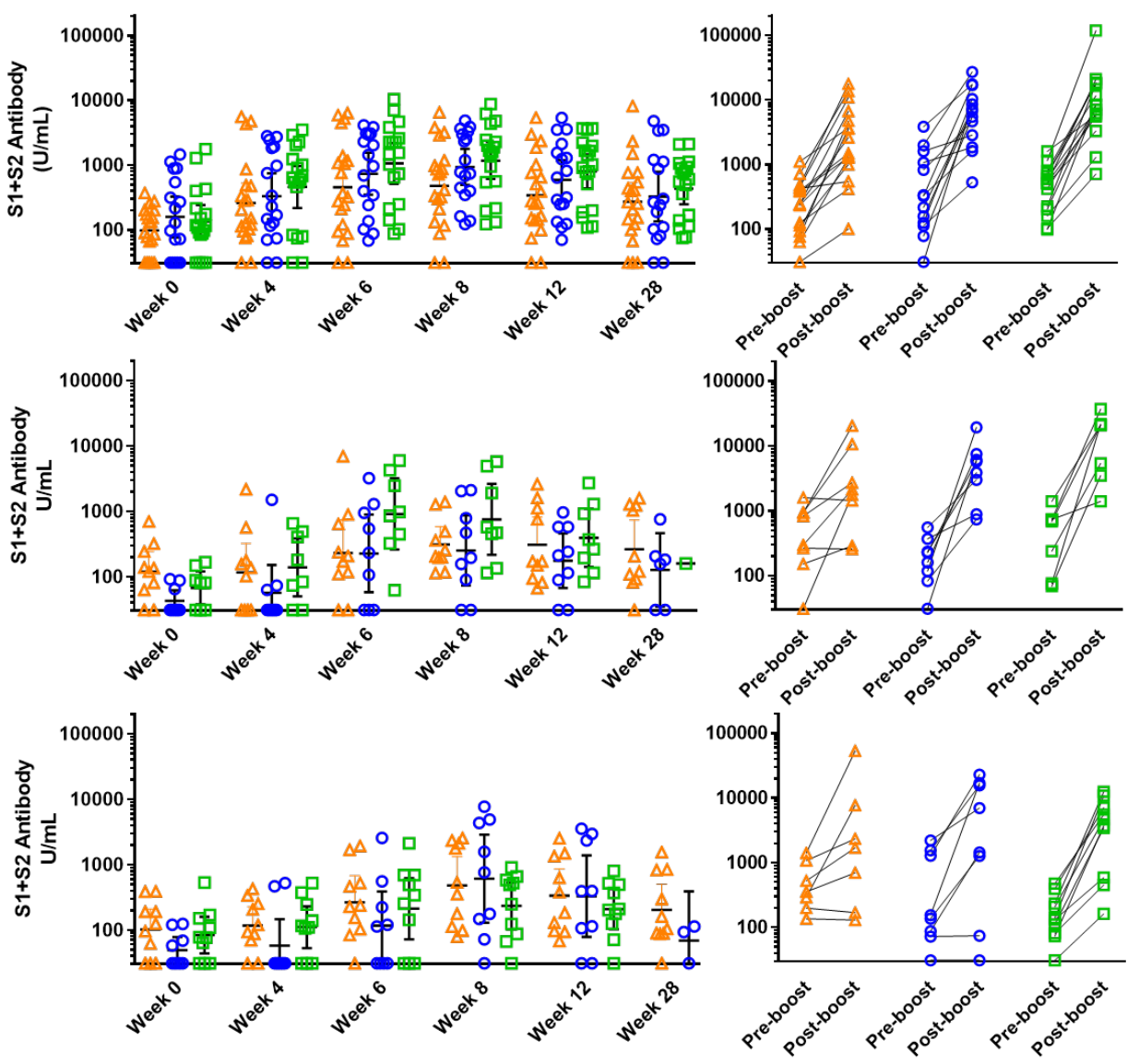
medRxiv preprint doi: https://doi.org/10.1101/2021.10.06.21264584; this version posted January 25, 2022. The copyright holder for this preprint (which was not certified by peer review) is the author/funder, who has granted medRxiv a license to display the preprint in perpetuity.

All rights reserved. No reuse allowed without permission.

Supplementary Figure 2: Antibody responses in SARS-CoV-2 convalescent donors.

Plasma from convalescent donors $(n=38)$ was obtained. A) Functional antibodies were assessed using a pseudovirus neutralization assay. The inhibition dilution where $50 \%$ neutralization occurs $\left(\mathrm{ID}_{50}\right)$ is plotted. B) Binding antibody concentrations to the Spike trimer were measured using ELISA.
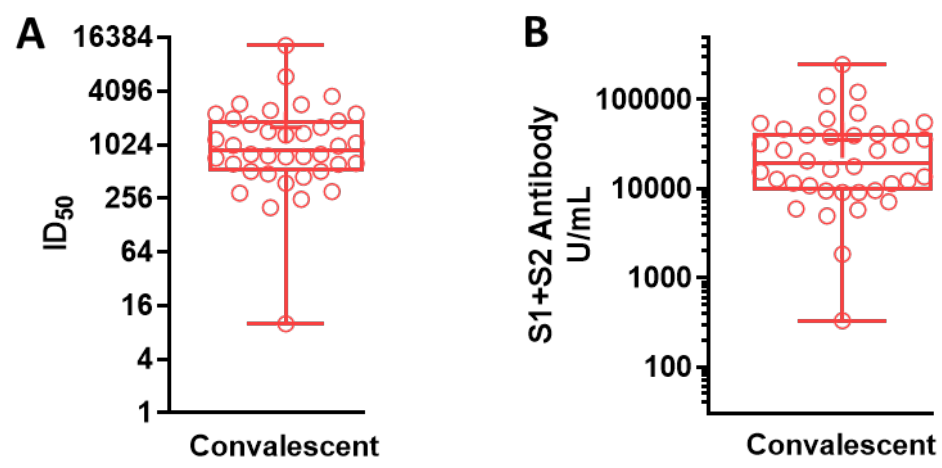


\section{Supplementary Figure 3: INO-4800 induces cellular responses to SARS-CoV-2 Spike across all age groups $(18-50,51-64$, and $\geq 65$ years).}

A) Longitudinal increases in spike antigen specific spot forming units per $10^{6}$ PBMCs over baseline in the IFN-g ELISpot are plotted. The left panel includes $n=40$ participants in the $0.5 \mathrm{mg}$ dose group ( $n=20$ 18-50 year olds, $n=1051-64$ year olds and $n=10 \geq 65$ year olds), $n=35$ participants in the $1.0 \mathrm{mg}$ dose group $(n=1718-50$ year olds, $n=951-64$ year olds and $n=9 \geq 65$ year olds) and $n=36$ participants in the $2.0 \mathrm{mg}$ dose group $(n=1818-50$ year olds, $n=851-64$ year olds and $n=10 \geq 65$ year olds). The right panel includes only participants with paired data available $n=34(n=1918-50$ year olds, $n=8$ 51-64 year olds and $n=7 \geq 65$ year olds), $n=24(n=1018-50$ year olds, $n=7,51-64$ year olds and $n=7 \geq 65$ year olds $)$ and $n=28(n=1418-50$ year olds, $n=5$ 51-64 year olds and $n=9 \geq 65$ year olds) participants in the $0.5 \mathrm{mg}, 1.0 \mathrm{mg}$, and $2.0 \mathrm{mg}$ dose groups, respectively.

B) Example gating strategy for flow cytometry assays.

C-D) Intracellular cytokine staining for IFN-g (purple) IL-2 (gray), TNF-a (blue) or any of the three cytokines (red) are plotted from samples collected at baseline or post-dose 2 . The graphs include $n=40$ participants in the $0.5 \mathrm{mg}$ dose group $(n=2018-50$ year olds, $n=1051-64$ year olds and $\mathrm{n}=10 \geq 65$ year olds), $\mathrm{n}=35$ participants in the $1.0 \mathrm{mg}$ dose group $(\mathrm{n}=19$ 18-50 year olds, $\mathrm{n}=1051$ 64 year olds and $n=10 \geq 65$ year olds) and n=36 participants in the 2.0 mg dose group ( $n=19$ 1850 year olds, $n=1051-64$ year olds and $n=10 \geq 65$ year olds). Open symbols represent individual participants, the box extends from the $25^{\text {th }}$ to the $75^{\text {th }}$ percentile, line inside the box is the median, and the whiskers extend from the minimum to maximum values. The mean is denoted with a "+" sign. Wilcoxon signed-rank was used to assess significance versus baseline. The dose groups are represented by triangles $(0.5 \mathrm{mg})$, circles $(1.0 \mathrm{mg})$ and squares $(2.0 \mathrm{mg})$. 

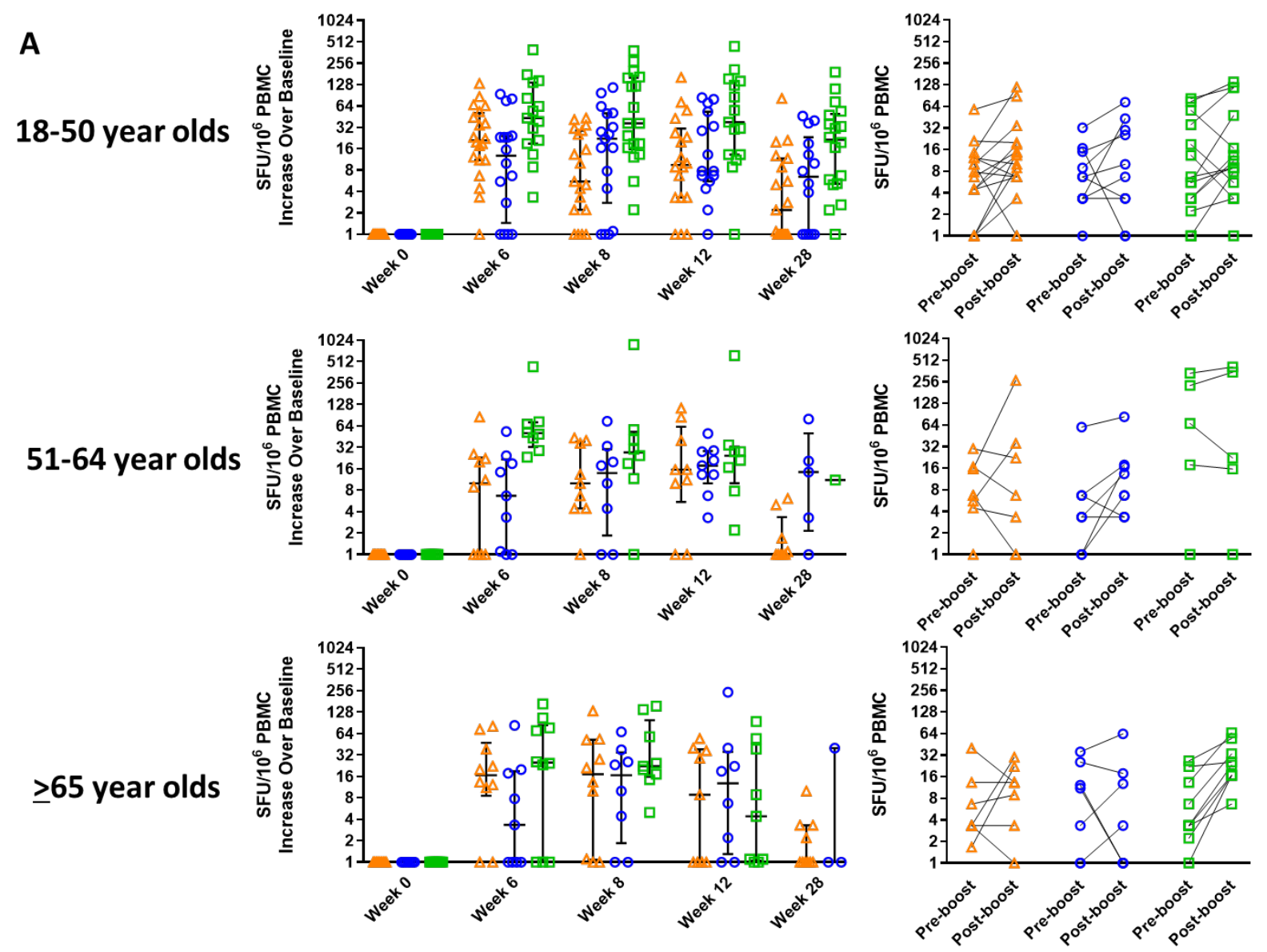

$\geq 65$ year olds

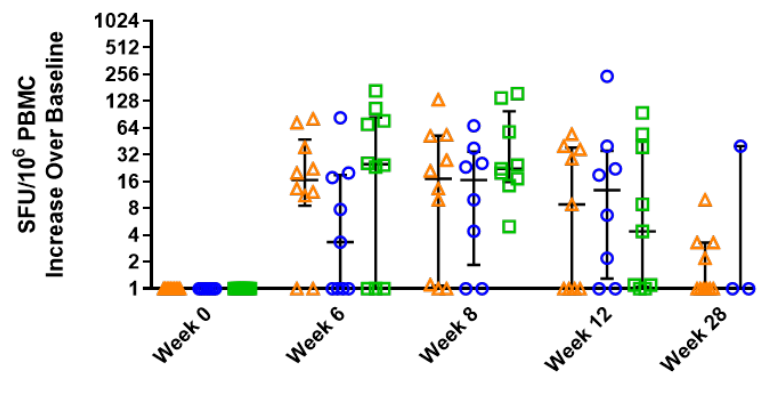

B
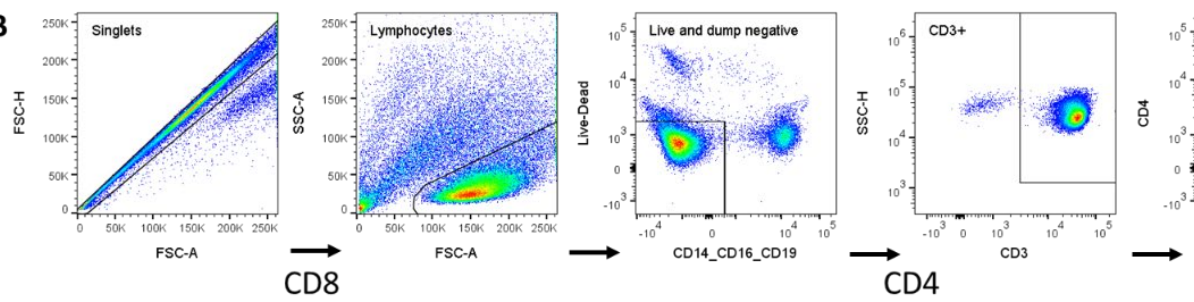

$\mathrm{CD} 4+$
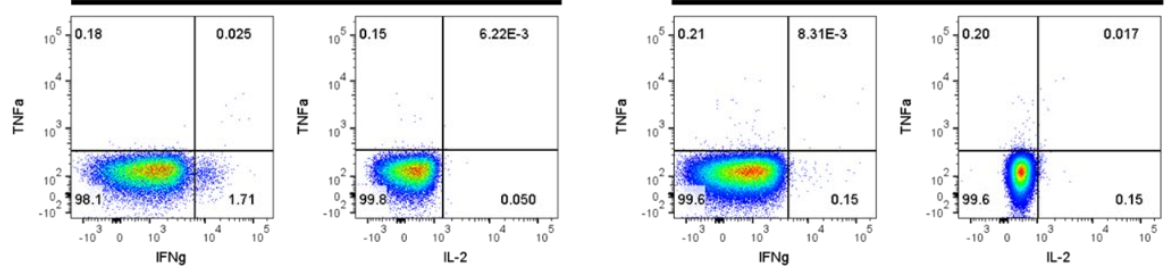


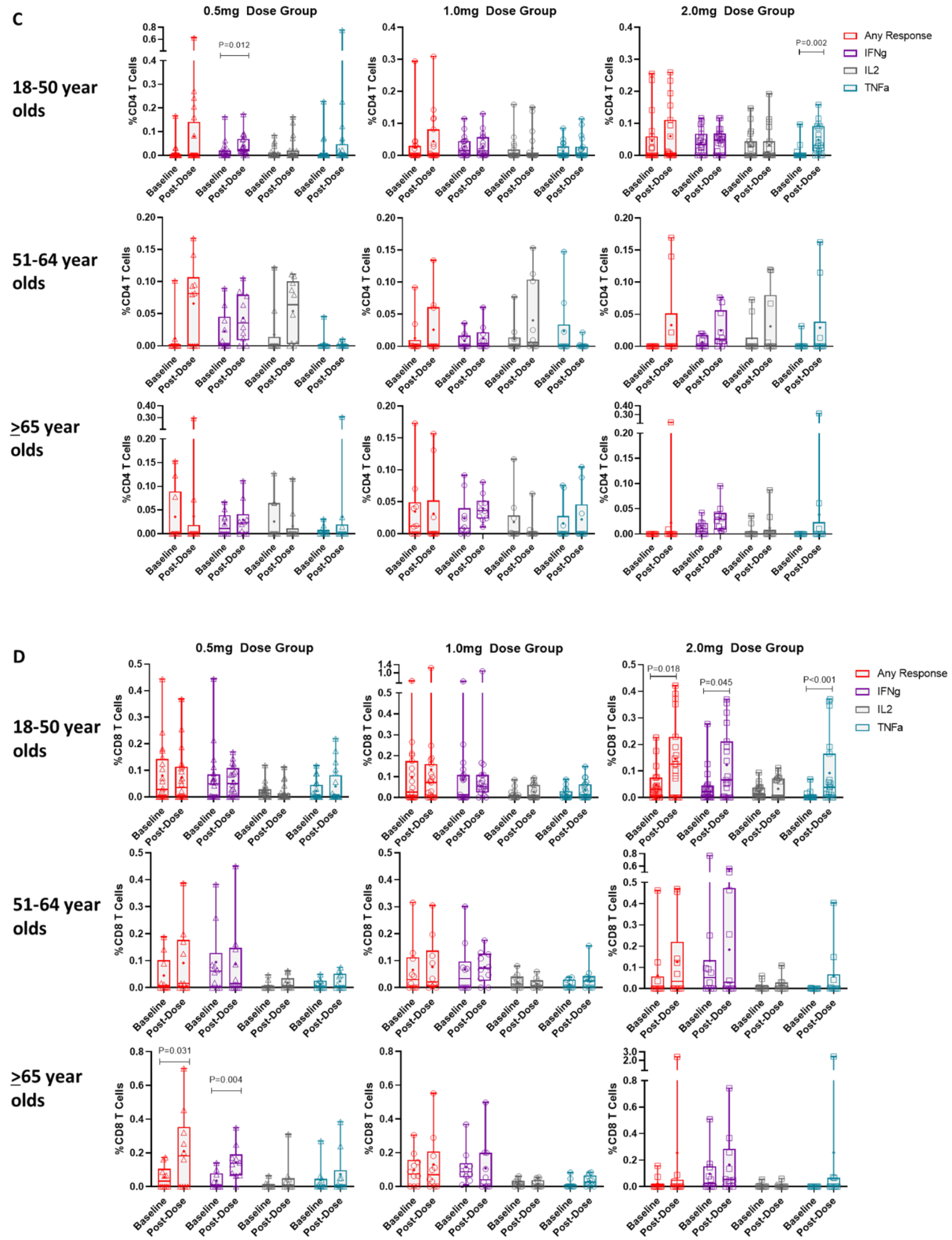

